\title{
Hyperactivation of P2X7 receptors as a culprit of COVID-19 neuropathology
}

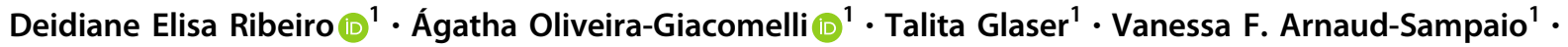 \\ Roberta Andrejew ${ }^{1} \cdot$ Luiz Dieckmann $^{2}$ - Juliana Baranova ${ }^{1}$. Claudiana Lameu ${ }^{1}$ Mariusz Z. Ratajczak ${ }^{3}$. \\ Henning Ulrich $\mathbb{1 D}^{1}$
}

Received: 22 July 2020 / Revised: 4 November 2020 / Accepted: 17 November 2020 / Published online: 16 December 2020

(c) The Author(s), under exclusive licence to Springer Nature Limited 2020

\begin{abstract}
Scientists and health professionals are exhaustively trying to contain the coronavirus disease 2019 (COVID-19) pandemic by elucidating viral invasion mechanisms, possible drugs to prevent viral infection/replication, and health cares to minimize individual exposure. Although neurological symptoms are being reported worldwide, neural acute and long-term consequences of SARS-CoV-2 are still unknown. COVID-19 complications are associated with exacerbated immunoinflammatory responses to SARS-CoV-2 invasion. In this scenario, pro-inflammatory factors are intensely released into the bloodstream, causing the so-called "cytokine storm". Both pro-inflammatory factors and viruses may cross the blood-brain barrier and enter the central nervous system, activating neuroinflammatory responses accompanied by hemorrhagic lesions and neuronal impairment, which are largely described processes in psychiatric disorders and neurodegenerative diseases. Therefore, SARS-CoV-2 infection could trigger and/or worse brain diseases. Moreover, patients with central nervous system disorders associated to neuroimmune activation (e.g. depression, Parkinson's and Alzheimer's disease) may present increased susceptibility to SARS-CoV-2 infection and/or achieve severe conditions. Elevated levels of extracellular ATP induced by SARS-CoV-2 infection may trigger hyperactivation of P2X7 receptors leading to NLRP3 inflammasome stimulation as a key mediator of neuroinvasion and consequent neuroinflammatory processes, as observed in psychiatric disorders and neurodegenerative diseases. In this context, P2X7 receptor antagonism could be a promising strategy to prevent or treat neurological complications in COVID-19 patients.
\end{abstract}

\section{Introduction}

Severe acute respiratory syndrome coronavirus 2 (SARSCoV-2) was first identified in December 2019 as the infectious agent of coronavirus disease 2019 (COVID-19).

These authors contributed equally: Deidiane Elisa Ribeiro, Ágatha Oliveira-Giacomelli

Henning Ulrich

henning@iq.usp.br

1 Department of Biochemistry, Institute of Chemistry, University of São Paulo, São Paulo, Brazil

2 Department of Psychiatry, Federal University of São Paulo, São Paulo, Brazil

3 Stem Cell Program at the Department of Medicine, University of Louisville, Kentucky, KY, USA
SARS-CoV-2 invades cells using prominent spike protein, which binds to cellular membrane receptors. Host cell receptors recognized by SARS-CoV-2 spike proteins include angiotensin-converting enzyme 2 (ACE2) $[1,2]$ and CD147 (basigin) [3,4] besides involving virus spike protein priming/processing by transmembrane serine protease 2 (TMPRSS2) [5]. SARS-CoV-2 enters the cell through receptor-mediated endocytosis or receptorindependent entry, as shown for HEK293/hACE2 cells [6]. The challenging question is, whether the infection can occur through extracellular microvesicles shed from infected cells. Such mechanism is often called "trojan horse" and has been proposed for human immunodeficiency virus (HIV) [7, 8]. Although neural acute and longterm consequences of SARS-CoV-2 infection are still unknown, neurological symptoms are being reported worldwide. Therefore, urgent challenges are to identify, ameliorate, or even eliminate these effects. 
COVID-19 complications are widely associated with exacerbated immunoinflammatory responses upon SARSCoV-2 lung invasion. In this scenario, pro-inflammatory factors are intensely released, the so-called "cytokine storm", which enter the bloodstream, and reach other organs (Fig. 1A) [9]. In this sense, both pro-inflammatory factors and viruses can cross the blood-brain barrier (BBB) and enter the central nervous system (CNS), initiating a neuroinflammatory process [10]. BBB permeability is increased in patients with neurodegenerative diseases, which could facilitate SARS-CoV-2 neuroinvasion. In addition, the neuroinflammatory insult could increase susceptibility to neurodegeneration in patients who are not yet suffering from these diseases. While confirmation of this hypothesis may take years, possible long-term consequences of COVID-19 need to be highlighted.
Neurotropism of human coronaviruses has already been demonstrated in small animals and in autoptic studies of brains infected with the severe acute respiratory syndrome coronavirus (SARS-CoV) [11], which was responsible for the severe acute respiratory syndrome (SARS) outbreak during 2002-2003. Image studies [12, 13] and postmortem examination [14] of the brain of COVID-19 patients also revealed hemorrhagic lesions accompanied by neuronal injury and neuroinflammation signals. These brain pathologies are described as both etiological factors and consequences of psychiatric disorders and neurodegenerative diseases [15]. Therefore, it is plausible to suggest that patients with COVID-19 are prone to develop neurological disorders, as well as patients suffering from these conditions are more susceptible to SARS-CoV-2 infection. In this context, understanding the mechanisms underlying

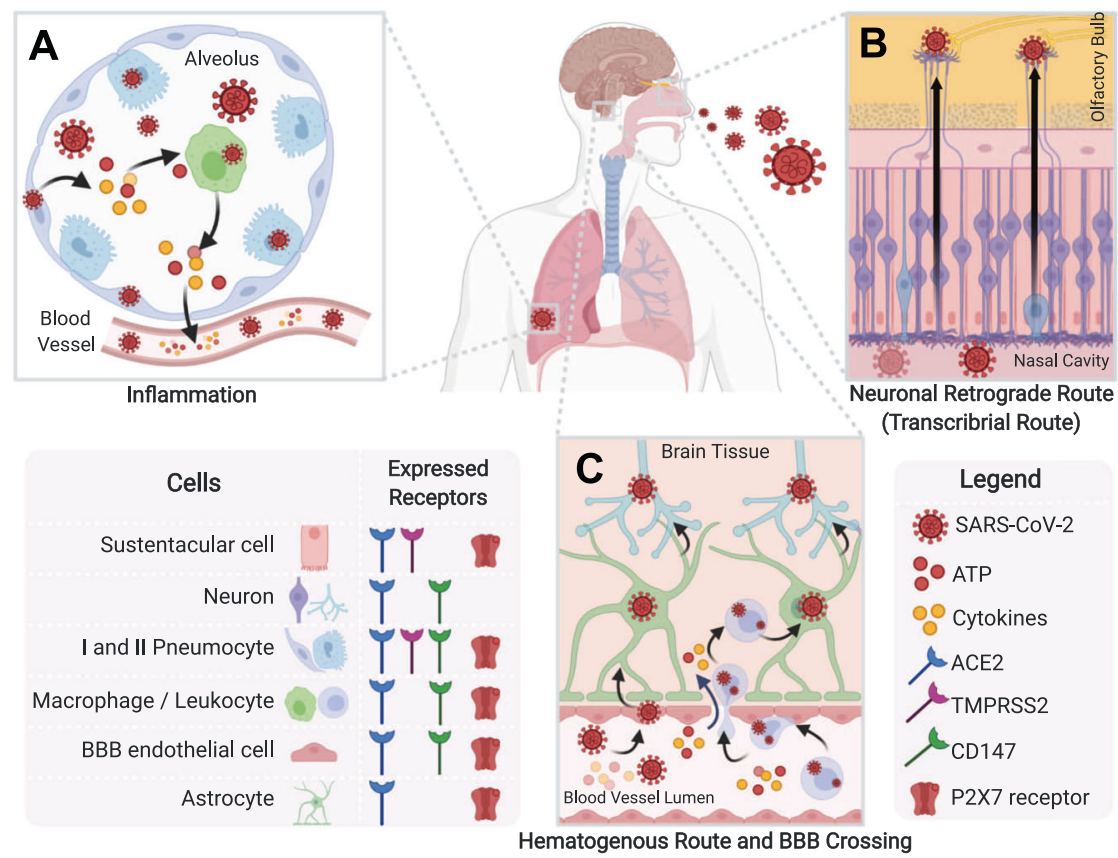

Fig. 1 Possible routes of SARS-CoV-2 infection of the central nervous system and cytokine storm involvement. A In the lung, SARS-CoV-2 may infect type I and II pneumocytes (dark and light blue, respectively) and proliferate in these cells. SARS-CoV-2 invades type I pneumocytes following binding to TMPRSS2 and possibly CD147 receptors, whereas invasion of type II pneumocytes additionally involves binding to ACE2 [171, 172]. The distressed cells release pro-inflammatory factors and DAMPs, such as ATP, which recruit macrophages (green) by activating $\mathrm{P} 2 \mathrm{X} 7$ receptors. These macrophages increase the release of cytokines, chemokines, and ATP, inducing the cytokine storm. ATP could also activate $\mathrm{P} 2 \mathrm{X} 7$ receptors in type I pneumocytes. These pro-inflammatory factors, as well as the virus, reach the circulatory system and can induce inflammatory responses in other tissues, in part through the activation of P2X7 receptors by released ATP. B In the neuronal retrograde pathway, the virus infects peripheral neurons and uses synaptic connections to reach the CNS. In the transcribrial pathway, SARS-CoV-2 can multiply in sustentacular cells (pink) of the nasal cavity, using ACE2 and

TMPRSS2 receptors for infection or in olfactory sensory neurons (purple) following binding to CD147 receptors. Thus, the virus uses these neurons to reach the CNS olfactory bulb (yellow) and infect cells using ACE2 receptors [173]. Sustentacular cells express P2X7 receptors [174]. $\mathbf{C}$ Once in the bloodstream, the virus can reach and infect blood-brain barrier (BBB) endothelial cells (pink), through binding to ACE2 and CD147 [175], and perivascular astrocytes (green), through binding to ACE2 [172]. In COVID-19, the BBB shows increased permeability due to the inflammatory process and death of endothelial cells and astrocytes, possibly resulting from P2X7 receptor activation. Although not yet confirmed, the virus could infect monocytes (purple) using CD147 receptors [176], which in turn can pass the BBB. Inside the CNS, the virus can infect neurons (blue) and other neural cell, by binding to ACE2 [173] and possibly to CD147 [177]. Moreover, cytokines present in circulating blood can also reach the CNS through $\mathrm{BBB}$ breaches and induce neuroinflammation, sensitizing the brain. Created with BioRender.com. 
COVID-19 neuropathology is essential for the development of therapeutic strategies.

Hyperactivation of $\mathrm{P} 2 \mathrm{X} 7$ receptors is closely related to inflammatory processes since they are stimulated by ATP released from distressed cells and induce inflammasome activation [16-18]. P2X7 receptors are ATP-gated ion channels widely expressed in the CNS [19], and their activation induced by viral infection leads to molecular (mainly neuroimmune response activation, reactive oxygen species (ROS) formation, and glutamate release) and behavioral alterations $[17,20]$ as well as to mental disorders [21].

Based on this, we postulate that both, neuroinvasion through the BBB and hyperstimulation of neuroimmune responses observed during COVID-19 infection, are mediated by hyperactivation of the $\mathrm{P} 2 \mathrm{X} 7$ receptor, possibly through NLRP3 inflammasome stimulation. This cascade could lead to COVID-19-associated psychiatric disorders and neurodegenerative diseases. Thus, $\mathrm{P} 2 \mathrm{X} 7$ receptor antagonism would be a promising strategy to prevent or treat neurological complications in infected patients. This concept will be discussed in detail in our review.

\section{Neurological symptoms in COVID-19}

An increasing number of studies reports the manifestation of neurological symptoms in patients with COVID-19. As reviewed by Pezzini and Padovani, neurological manifestations affect between 4.2 and $100 \%$ of studied patients: dizziness (prevalent in 7.6-46.1\%), headache (5.1-77.1\%), impaired consciousness (9.5-64.1\%), and seizures (1.2-26\%) [22]. Noteworthy, in COVID-19 patients presenting at least one neurological symptom, the prevalence of acute stroke (2.9-76.8\%), confusion (14.2-65\%), and encephalitis (0-27.9\%) stands out. COVID-19 patients also present other nervous system symptoms, such as impaired taste (10-19.2\%) and smell (6-21.7\%), dysautonomia (4.3-12\%), and acute inflammatory demyelinating polyneuropathy $(0-16,2 \%)$ [22].

Together with an acute cerebrovascular disorder, all symptoms are correlated with the consequences of strokes or micro-strokes [23]. Moreover, reported impaired olfaction could be due to CNS invasion or direct damage of olfactory sensory neurons in the nasal cavity [24].

Psychiatric symptoms are being reported in COVID-19 patients, healthcare workers and in the general population. Table 1 summarizes meta-analysis and systematic reviews on these topics. The studies were selected after searching the PubMed data base on September 20, 2020 for the terms: "COVID-19 or SARS-CoV-2 or severe acute respiratory syndrome coronavirus 2 ) and (mental health or psychological health or depression or anxiety or PTSD or PTSS or post-traumatic stress disorder or post-traumatic stress symptoms)".

Although studies on psychiatric symptoms accompanying SARS-CoV-2 illness need further investigation, the available data indicate that COVID-19 patients mainly present depressive symptoms (42-65\%), anxiety (37-47\%), and PTSS (93-96\%). Noteworthy, stress caused by the pandemic situation (e.g., social isolation, fear of infection, and financial instability) may also induce depressive symptoms (14.6-48.3\%), anxiety (6.33-50.9\%), and PTSS (7-53.8\%) in the general population. The stressful situation of healthcare workers, specially the fear to infect relatives, may lead to depressive symptoms (12.2-26.3\%), anxiety (13-29\%), and PTSS (3-20.7\%) as well.

In this scenario, the following proposals are raised and require additional studies: (1) alterations induced by stress exposure (e.g., immune hyperactivation) could both facilitate SARS-CoV-2 infection as well as aggravate COVID19 symptoms; (2) neurological symptoms are probably not specifically related to SARS-CoV-2 invasion, but they are a general consequence of infectious disorders (which include sickness behavior), stressful events (pandemic situation), and/or immune response hyperactivation ("cytokine storm"); (3) genetic and/or environmental factors affect the development of neurological symptoms, as these responses highly vary across the population. Clarifying these issues would improve the understanding on SARS-CoV-2 infection and direct the search for treatments.

\section{SARS-CoV-2 neuroinvasion}

COVID-19 patients are presenting neurological symptoms worldwide. Although brain analysis of these patients is not being widely performed, a study detected SARS-CoV2 in 8 of 21 postmortem brain tissues, based on reverse transcriptase polymerase chain reaction [25]. Moreover, neuroinvasion capability of SARS-CoV-2 was observed in human brain organoids, especially in neuronal cells, such as neural progenitor and radial glial cells, accompanied by increased cell death [26]. The same study found positive staining for SARS-CoV-2 spike protein in the brain of three COVID-19 patients, with different expression patterns and staining intensities [26]. Neuroinvasion potential of SARS-CoV-2 was demonstrated in mice expressing human ACE2 and correlated with increased mortality independent from respiratory infection [26]. SARS-CoV-2 also seems to invade infants' brains, since immunohistochemical analysis of the postmortem brain of a 1-year-old infant showed positive staining in the choroid plexus, ventricles and cerebral cortex [27]. Remarkably, a case report demonstrated the presence of SARS-CoV-2 viral particles in neural tissue and brain capillary 
Table 1 Summary of systematic reviews and meta-analysis of psychiatric symptoms exhibited by the general population, healthcare workers, COVID-19 patients, and psychiatric patients due to the COVID-19 pandemic outbreak.

\begin{tabular}{|c|c|c|c|c|c|}
\hline Psychiatric outcome & Prevalence \% $(95 \% \mathrm{CI})$ & Total sample size & Sample location & $\begin{array}{l}\text { Studies } \\
\text { included }\end{array}$ & Reference \\
\hline \multicolumn{2}{|l|}{ Depression } & 173,662 & \multirow{5}{*}{$\begin{array}{l}\text { China, Iran, Italy, Singapore, } \\
\text { Vietnam }\end{array}$} & \multirow[t]{5}{*}{50} & \multirow[t]{5}{*}[178]{} \\
\hline Overall & $26 \%(20-33 \%)$ & & & & \\
\hline General population & $24 \%(14-36 \%)$ & & & & \\
\hline Healthcare workers & $25 \%(19-32 \%)$ & & & & \\
\hline COVID-19 patients & $42 \%(28-57 \%)$ & & & & \\
\hline \multicolumn{6}{|l|}{ Anxiety } \\
\hline Overall & $26 \%(21-31 \%)$ & & & & \\
\hline General population & $26 \%(20-32 \%)$ & & & & \\
\hline Healthcare workers & $24 \%(16-32 \%)$ & & & & \\
\hline COVID-19 patients & $37 \%(19-57 \%)$ & & & & \\
\hline \multicolumn{6}{|l|}{ Psychological distress } \\
\hline Overall & $34 \%(27-42 \%)$ & & & & \\
\hline General population & $26 \%(21-32 \%)$ & & & & \\
\hline Healthcare workers & $41 \%(19-65 \%)$ & & & & \\
\hline \multicolumn{6}{|l|}{ Stress } \\
\hline Overall & $34 \%(20-50 \%)$ & & & & \\
\hline General population & $36 \%(5-75 \%)$ & & & & \\
\hline Healthcare workers & $33 \%(19-50 \%)$ & & & & \\
\hline \multicolumn{6}{|l|}{ Post-traumatic stress symptoms } \\
\hline Overall & $27 \%(12-45 \%)$ & & & & \\
\hline General population & $15 \%(4-31 \%)$ & & & & \\
\hline Healthcare workers & $13 \%(11-16 \%)$ & & & & \\
\hline COVID-19 patients & $96 \%(95-97 \%)$ & & & & \\
\hline \multicolumn{6}{|l|}{ Poor sleep quality } \\
\hline Overall & $40 \%(25-57 \%)$ & & & & \\
\hline General population & $34 \%(12-60 \%)$ & & & & \\
\hline Healthcare workers & $43 \%(28-59 \%)$ & & & & \\
\hline COVID-19 patients & $82 \%(66-92 \%)$ & & & & \\
\hline \multicolumn{6}{|l|}{ Insomnia } \\
\hline Overall & $30 \%(12-52 \%)$ & & & & \\
\hline General population & $7 \%(7-8 \%)$ & & & & \\
\hline Healthcare workers & $37 \%(32-42 \%)$ & & & & \\
\hline Depression & & 93,569 & China, Denmark, Nepal, Spain, & 19 & [179] \\
\hline General population & $14.6-48.3 \%$ & & Turkey, USA & & \\
\hline \multicolumn{6}{|l|}{ Anxiety } \\
\hline General population & $6.33-50.9 \%$ & & & & \\
\hline \multicolumn{6}{|l|}{ Post-traumatic stress disorder } \\
\hline General population & $7-53.8 \%$ & & & & \\
\hline \multicolumn{6}{|l|}{ Psychological distress } \\
\hline General population & $34.43-38 \%$ & & & & \\
\hline \multicolumn{6}{|l|}{ Stress } \\
\hline General population & $8.1-81.9 \%$ & & & & \\
\hline Depression & & 17,330 & China & 8 & {$[180]$} \\
\hline Healthcare workers vs. professionals from other areas & $\begin{array}{l}12.2 \% \text { vs. } 9.5 \% \\
(\mathrm{OR}=1.3246 ; 95 \% \mathrm{CI} \\
1.0930-1.6053)\end{array}$ & & & & \\
\hline \multicolumn{6}{|l|}{ Anxiety } \\
\hline Healthcare workers vs. professionals from other areas & $\begin{array}{l}13.0 \% \text { vs. } 8.5 \% \\
(\mathrm{OR}=1.6152 ; 95 \% \mathrm{CI} \\
1.3283-1.9641)\end{array}$ & & & & \\
\hline Stress & & 63,439 & China, India, Iran, Iraq, Italy, & 17 & [181] \\
\hline General population & $29.6 \%(24.3-35.4 \%)$ & & Japan, Nepal, Nigeria, Spain, UK & & \\
\hline Asia & $27.9 \%(19.7-37.8 \%)$ & & & & \\
\hline Europe & $31.9 \%(23.1-42.2 \%)$ & & & & \\
\hline \multicolumn{6}{|l|}{ Anxiety } \\
\hline General population & $31.9 \%(27.5-36.7 \%)$ & & & & \\
\hline Asia & $32.9 \%(28.2-37.9 \%)$ & & & & \\
\hline Europe & $23.8 \%(16.2-33.5 \%)$ & & & & \\
\hline \multicolumn{6}{|l|}{ Depression } \\
\hline General population & $33.7 \%(27.5-40.6 \%)$ & & & & \\
\hline Asia & $35.3 \%(27.3-44.1 \%)$ & & & & \\
\hline
\end{tabular}


Table 1 (continued)

\begin{tabular}{|c|c|c|c|c|c|}
\hline Psychiatric outcome & Prevalence $\%(95 \% \mathrm{CI})$ & Total sample size & Sample location & $\begin{array}{l}\text { Studies } \\
\text { included }\end{array}$ & Reference \\
\hline $\begin{array}{l}\text { Europe } \\
\text { Psychological distress }\end{array}$ & $32.4 \%(21.6-45.5 \%)$ & N.R. & N.R. & 40 & [182] \\
\hline $\begin{array}{l}\text { Healthcare workers exposed to SARS/MERS/ } \\
\text { COVID-19 }\end{array}$ & $37.8 \%(28.4-48.2 \%)$ & & & & \\
\hline \multicolumn{6}{|l|}{ Burnout } \\
\hline $\begin{array}{l}\text { Healthcare workers exposed to SARS/MERS/ } \\
\text { COVID-19 }\end{array}$ & $34.4 \%(19.3-53.5 \%)$ & & & & \\
\hline \multicolumn{6}{|l|}{ Anxiety } \\
\hline $\begin{array}{l}\text { Healthcare workers exposed to SARS/MERS/ } \\
\text { COVID-19 }\end{array}$ & $29.0 \%(14.2-50.3 \%)$ & & & & \\
\hline \multicolumn{6}{|l|}{ Depressive symptoms } \\
\hline $\begin{array}{l}\text { Healthcare workers exposed to SARS/MERS/ } \\
\text { COVID-19 }\end{array}$ & $26.3 \%(12.5-47.1 \%)$ & & & & \\
\hline \multicolumn{6}{|l|}{ Post-traumatic stress disorder } \\
\hline $\begin{array}{l}\text { Healthcare workers exposed to SARS/MERS/ } \\
\text { COVID-19 }\end{array}$ & $20.7 \%(13.2-31 \%)$ & & & & \\
\hline Anxiety & & 162,639 & Argentina, Brazil, Chile, China, & 62 & [183] \\
\hline Overall & $33 \%(28-38 \%)$ & & $\begin{array}{l}\text { Denmark, Greece, India, Iran, } \\
\text { Israel, Italy, Japan, Mexico, }\end{array}$ & & \\
\hline General population & $32 \%(25-39 \%)$ & & Pakistan, Singapore, Spain, & & \\
\hline General population-Italy & $81 \%(80-83 \%)$ & & Turkey, Vietnam & & \\
\hline Healthcare workers & $26 \%(18-34 \%)$ & & & & \\
\hline Healthcare workers-Singapore & $7 \%(5-9 \%)$ & & & & \\
\hline Healthcare workers-Italy & $57 \%(52-63 \%)$ & & & & \\
\hline Psychiatric patients with moderate-to-severe anxiety & $24 \%(14-33 \%)$ & & & & \\
\hline COVID-19 patients & $47 \%(34-61 \%)$ & & & & \\
\hline COVID-19 patients with type 2 diabetes-India & $40 \%(30-50 \%)$ & & & & \\
\hline COVID-19 patients with Parkinson's Disease-Iran & $82 \%(74-88 \%)$ & & & & \\
\hline \multicolumn{6}{|l|}{ Depression } \\
\hline Overall & $28 \%(23-32 \%)$ & & & & \\
\hline General population & $27 \%(22-33 \%)$ & & & & \\
\hline General population-Italy & $67 \%(65-69 \%)$ & & & & \\
\hline Healthcare workers & $25 \%(17-33 \%)$ & & & & \\
\hline Healthcare workers-Singapore & $9 \%(7-12 \%)$ & & & & \\
\hline Healthcare workers-China & $51 \%(48-53 \%)$ & & & & \\
\hline $\begin{array}{l}\text { Psychiatric patients with moderate-to-severe } \\
\text { depression }\end{array}$ & $22 \%(13-32 \%)$ & & & & \\
\hline COVID-19 patients-China & $65 \%(51-77 \%)$ & & & & \\
\hline \multicolumn{6}{|l|}{ Distress } \\
\hline Overall & $35 \%(23-47 \%)$ & & & & \\
\hline \multicolumn{6}{|l|}{ Stress } \\
\hline Overall & $40 \%(20-60 \%)$ & & & & \\
\hline \multicolumn{6}{|l|}{ Insomnia } \\
\hline Overall & $32 \%(25-39 \%)$ & & & & \\
\hline \multicolumn{6}{|l|}{ Post-traumatic stress symptoms/disorders } \\
\hline General population & $16 \%(15-17 \%)$ & & & & \\
\hline Healthcare workers & $3 \%(2-4 \%)$ & & & & \\
\hline COVID-19 patients & $93 \%(92-95 \%)$ & & & & \\
\hline Anxiety & & 33,062 & China, Singapore & 12 & [184] \\
\hline Healthcare workers & $23.21 \%(17.77-29.13 \%)$ & & & & \\
\hline Male & $20.92 \%(11.86-31.65 \%)$ & & & & \\
\hline Female & $29.06 \%(20.21-38.78 \%)$ & & & & \\
\hline \multicolumn{6}{|l|}{ Depression } \\
\hline Healthcare workers & $22.93 \%(13.16-34.38 \%)$ & & & & \\
\hline Male & $20.34 \%(11.57-30.75 \%)$ & & & & \\
\hline Female & $26.87 \%(15.39-40.09 \%)$ & & & & \\
\hline \multicolumn{6}{|l|}{ Insomnia } \\
\hline Healthcare workers & $34.32 \%(27.45-41.54 \%)$ & & & & \\
\hline
\end{tabular}

CI Confidence interval, OR Odds ratio, N.R. Not reported

endothelium of a Parkinson's disease patient, which was associated with the worsening of neurological symptoms [28].
However, the mechanism of SARS-CoV-2 infection of the brain is still unknown. Invasion routes of the CNS by other viruses include: (a) the hematogenous route, in which 
viruses use the bloodstream to reach and invade epithelial cells from the BBB or the blood-cerebrospinal fluid barrier, or use leukocytes as a vector to enter the CNS; (b) the neuronal retrograde route, in which viruses invade peripheral neurons and reach CNS, including the transcribrial route, using olfactory sensory neurons in the nasal cavity (Fig. 1B) [10].

In the hematogenous route, the virus must be capable of crossing the BBB (Fig. 1C). This barrier is composed of endothelial cells, pericytes, and astrocytes. The restricted permeability of the BBB is a reflex of the connection between brain microvascular endothelial cells and tight cell-cell junctions. The BBB is disrupted under inflammatory conditions $[29,30]$. In the "Trojan horse" mechanism of CNS invasion, infected leukocytes pass the BBB. This mechanism is observed for HIV, and since SARS-CoV can infect immune cells, it is likely that SARS-CoV-2 also uses this route toward the CNS [10]. Viral infection also affects BBB integrity by different mechanisms, including phosphorylation of tight junction proteins, disruption of the basal lamina or of the actin cytoskeleton, or by invading BBBepithelial cells and furthermore astrocytes [10, 31].

Evidence of CNS invasion through neuronal retrograde routes was reported for coronaviruses, such as $\mathrm{HCoV}$ OC43, HEV67 and avian bronchitis virus [32]. Once respiratory and digestive tracts of animals were infected, coronaviruses invaded peripheral neurons and passed through synaptic connections until they reached medullary neurons and subsequently other neurons and glial cells of the CNS [32]. As the main entry route of SARS-CoV-2 in humans, cells from the nasal cavity could be susceptible to viral infection and replication. Studies reported that human olfactory sustentacular cells express both ACE2 and TMPRSS2 virus receptors [33]. Although current literature data reports that human olfactory sensory neurons do not express these proteins, they express CD147 that could allow SARS-CoV-2 neuroinvasion (Fig. 1) [33, 34]. In fact, SARS-CoV, MERS-CoV, and HCoV-OCR43 were able to invade the murine CNS using the transcribrial route, infecting olfactory sensory neurons of nasal cavity, and passing to other neural cells, indicating that SARS-CoV-2 could use the same mechanism [24, 35-37].

\section{Inflammation and CNS-related lethality of COVID-19}

Severe COVID-19 patients commonly develop the Acute Respiratory Distress Syndrome [38], which is characterized by inflammatory injury to the alveoli-capillary membrane, leading to lung over-permeability and increased pulmonary edema fluid into the airspaces, resulting in the lack of respiratory capacity [39]. This overreaction of the innate immune system against viral infection induces the so-called "cytokine storm", comprising of: (1) the release of large amounts of several pro-inflammatory cytokines (interferons IFN $\alpha$ and IFN $\gamma$, interleukins [IL-1 $\beta$, IL-6, IL-12, IL-18 and IL-33], tumor necrosis factor [TNF]- $\alpha$, and transforming growth factor $[\mathrm{TGF}]-\beta$ ) and chemokines (CXCL10, CXCL8, CXCL9, CCL2, CCL3, CCL5); (2) release of renin-angiotensin aldosterone system (RAAS) mediators and increasing blood levels of angiotensin II (Ang II); and lately (3) amplification of the innate immune system response and activation of its major humoral arm, the complement cascade (ComC) [40].

Novel evidence indicates that COVID-19-released mediators merge on a common pathway, upregulating cytosolic danger sensing pattern recognition receptor, which is part of a multiprotein complex of the innate immune system that is called inflammasome, and recognizes both pathogenassociated molecular patterns and self-derived dangerassociated molecular patterns (DAMPs) or alarmines [41].

Importantly, upon inflammasome protein assembly and activation, pro-caspase 1 protein is cleaved to functional caspase 1 , whose main function is the conversion of the inactive and intracellularly stored pro-inflammatory cytokines, pro-IL-1 $\beta$ and pro-IL-18, into their active forms that are released from cells. This release is facilitated by creating gasdermin D (GSDMD) pore channels in cell membranes. In addition to these two cytokines, gasdermin D channels also mediate the release of several biologically active DAMPs or alarmines, including extracellular ATP, high mobility group protein $\mathrm{B} 1$, and $\mathrm{S} 100$ calcium-binding proteins A8 and A9 (S1008/9a) [42].

There are various inflammasome subtypes. The NLRP3 inflammasome protein complex is usually involved in virus infections and consists of NLRP3 protein, apoptosisassociated speck-like protein containing a CARD (ASC) and pro-caspase-1, and remains in the cytosol in steadystate conditions in an inactive form. Upon activation, it becomes a multiprotein aggregate composed of several NLRP3 molecules (speck complexes), each containing NLRP3 protein, ASC, and pro-caspase 1 [41].

We consider the NLRP3 inflammasome as a trigger of the cytokine storm, as seen in COVID-19 patients, that may be induced by $\mathrm{P} 2 \mathrm{X} 7$ receptor activation, including in the brain (Fig. 2). Once SARS-CoV-2 spike protein interacts with ACE2, macrophages/microglia cells can potentiate the immune response through the cleavage of fragments complement component $3 \mathrm{a}$ and $5 \mathrm{a}$ (C3a and $\mathrm{C} 5 \mathrm{a}$, respectively) and non-lytic C5b-C9 membrane attack complex by ComC, thus activating the NLRP3 inflammasome [41]. Moreover, NLRP3 inflammasome activation during COVID-19 infection is usually triggered by Ang II, which binds to the angiotensin type 1 receptor $\left(\mathrm{AT}_{1} \mathrm{R}\right)$, leading to vessel contraction and increasing blood pressure. In normal conditions, Ang II is converted by the ACE2 receptor into angiotensin 1-7 (Ang 1-7) [43]. Ang II activates the $\mathrm{AT}_{1} \mathrm{R}$, 


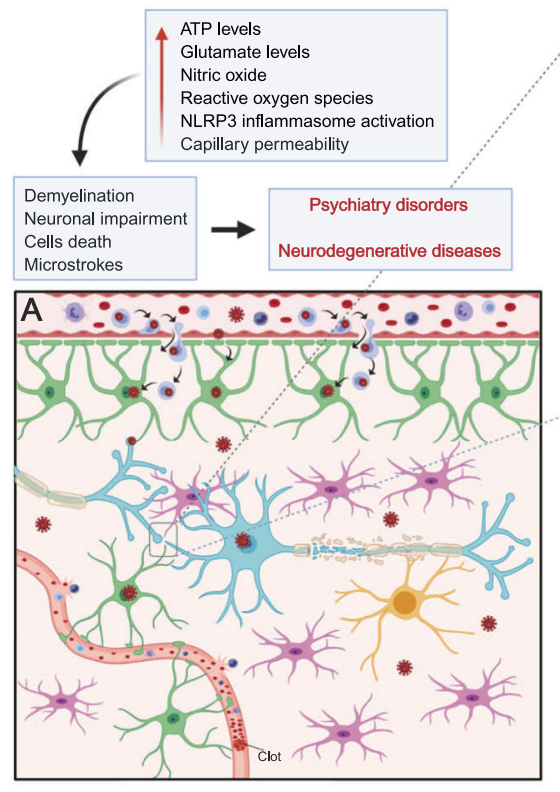

Fig. 2 P2X7 receptor-mediated neuroinflammatory implications of SARS-COV2 invasion in the CNS. A SARS-CoV-2 may alter brain function by reaching the central nervous system (described in Fig. 1) and/or through the cytokine storm-mediated effects. The result is a neuroinflammatory process characterized by microglia (pink) hyperactivation, astrocyte (green) stimulation, and demyelination (yellow caps) of neurons (blue). In addition, the cytokine storm induces bloodclot formation and increased capillary (red) permeability resulting in embolic and hemorrhagic strokes, respectively. B In a molecular view, the distressed cells release pro-inflammatory cytokines (yellow circles) and ATP (red circles). ATP activates P2X7 receptors (red) expressed mainly in microglia (pink) and astrocytes (green) resulting in increased $\mathrm{Ca}^{2+}$ influx and glutamate (purple circles) release. Glutamate activates NMDA receptors expressed in nerve terminals (blue), which enable $\mathrm{Ca}^{2+}$-dependent exocytosis of ATP and more glutamate release. In this way, an auto regenerative loop is formed causing a massive release of these neurotransmitters augmenting excitotoxicity and cell death. In the postsynaptic neuron (blue), increased $\left[\mathrm{Ca}^{2+}\right]_{i}$ leads to $\mathrm{Ca}^{2+}$-calmodulin $(\mathrm{CaM})$ complex formation and consequent nNOS activation. $\mathrm{NO}$ production mediates neurotoxicity via several mechanisms. NO interacts with the iron-sulfur centers in the mitochondrial electron transport chain impairing cellular energy production. NO also produces reactive nitrogen species and reactive oxygen species (ROS). Reaction of $\mathrm{NO}$ and superoxide ion $\left(\mathrm{O}_{2}{ }^{-}\right.$, formed by $\mathrm{nNOS}$ under low arginine concentrations) generates peroxynitrite $\left(\mathrm{ONOO}^{-}\right)$and peroxynitrous acid $(\mathrm{ONOOH})$. These free radicals can also decompose into other reactive species, such as hydroxyl radical and peroxides.

inducing fibrosis, increased ROS release, vasoconstriction, and gut dysbiosis. In contrast, Ang 1-7 binds to Mas receptors (MasR), thus protecting against fibrotic formation, presenting antioxidant and vasodilatory effects. The problem with the conversion of Ang II into Ang 1-7 is that the ACE2 enzyme expressed on surface of cells is a COVID-19 receptor and is blocked or downregulated after binding of virus or even shed from the cell surface [43]. Extracellular ATP can also robustly trigger activation of the NLRP3 inflammasome through $\mathrm{P} 2 \mathrm{X} 7$ receptor activation. In

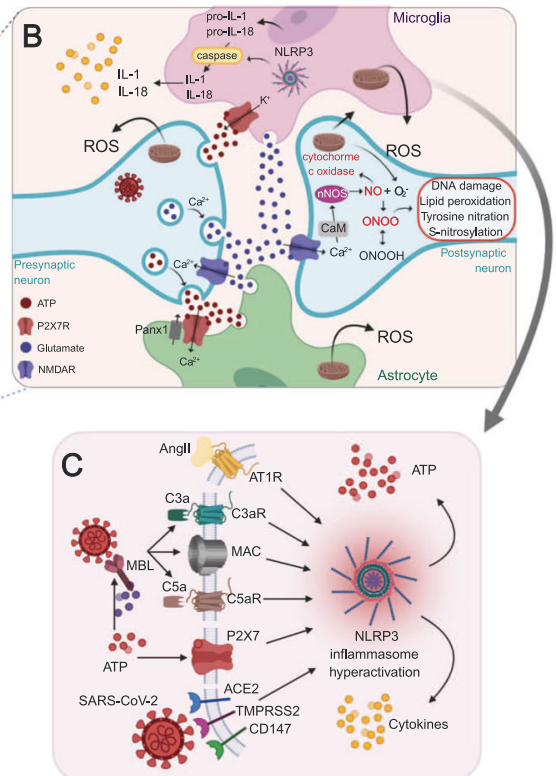

Oxidative stress from free radicals includes DNA damage, lipid peroxidation, tyrosine nitration, and excess S-nitrosylation. These structural changes can lead to protein misfolding and aggregation causing neuronal impairment and/or death. In microglia, $\mathrm{K}^{+}$efflux mediated by P2X7 receptor activation may trigger NLRP3 inflammasome assembly and activation through NIMA-related serine/threonine kinase 7 (Nek7) binding. NLRP3 inflammasome mediates the activation of caspase-1, which induces the maturation of interleukins (IL) by cleaving pro-IL$1 \beta$ and pro-IL-18 in IL-1 $\beta$ and IL-18, respectively. The mature forms of cytokines are secreted worsening the neuroinflammatory process established. C The hyperactivation of NPLR3 inflammasome and consequent release of cytokines and ATP can occur by different routes. (I) Activation of the renin-angiotensin system (RAS) leads to elevated levels of angiotensin II (Ang II) that binds to the $\mathrm{AT}_{1} \mathrm{R}$ receptor. (II) The $\mathrm{N}$ proteins of the SARS-CoV-2 virus activate ComC in a mannan binding lectin (MBL)-dependent manner, producing $\mathrm{C} 3 \mathrm{a}$ and $\mathrm{C} 5 \mathrm{a}$ anaphylatoxins and forming the non-lytic $\mathrm{C} 5 \mathrm{~b} / \mathrm{C} 9$ membrane attack complex (MAC). ATP can also activate MBL and induce this response. (III) $\mathrm{P} 2 \mathrm{X} 7$ receptor activation by ATP induces $\mathrm{K}^{+}$influx and inflammasome activation. (IV) SARS-CoV-2 invasion through ACE2, TMPRSS2 or CD147 activates the inflammasome in target cells. Hyperactivation of these pathways leads to activation of caspase 1, release of mature IL-1 $\beta$ and IL-18, the insertion of gasdermin D channels in the cell membrane and the release of danger-associated molecular pattern molecules (DAMPs), which amplify the innate immune response and may lead to cell death by pyroptosis. Created with BioRender.com.

addition, ATP is also released into the extracellular milieu upon NLRP3 inflammasome activation, promoting a strong positive feedback loop [44].

SARS-CoV-2-induced systemic inflammatory responses may also result in endothelial damage and consequently increased production of thrombin by inflammatory cytokines during sepsis in a bidirectional way, because inflammation activates coagulation, and coagulation augments inflammatory activity [45]. In this scenario, active inflammatory cells expressing specific protease activated receptors 
(PAR1-4) bind to thrombin, while the Toll-like receptor 4 interacts with fibrin. Supporting these events, patients in particular at younger age are often diagnosed with stroke and cardiovascular complications.

Recent evidence indicates that the occurrence of psychiatric disorders in patients is linked to "sterile" inflammation of the brain that may be initiated locally by some stressors affecting nervous tissue or occurs due to a systemic inflammation process $[17,46]$. This is supported by the observation that several inflammatory mediators and markers are detected in the peripheral blood of patients with psychiatric and neurodegenerative disorders [17, 46], which could worsen prognoses for COVID-19 outcome. Moreover, clinical data describe correlations between systemic chronic inflammatory processes and psychiatric disorders. This may also explain, why some reported antiinflammatory treatment strategies ameliorate neurodegeneration [17, 46]. In agreement, pathological increase of AngII-AT ${ }_{1}$ R-mediated activation of NLRP3 inflammasome may initiate psychosis. We believe that bioactive inflammatory mediators released during the cytokine storm, such as extracellular ATP, affect the CNS and may lead to its impairment, mainly through $\mathrm{P} 2 \mathrm{X} 7$ receptor activation, as we discuss in the following.

\section{Probable P2X7 receptor roles in COVID-19 processes}

The P2X7 receptor is widely expressed through the body [47], including in immune [48], lung [49], and CNS cells, mainly microglia and oligodendrocytes [50-52], whereas its expression in neurons and astrocytes is still under discussion [50, 51, 53-60]. During the progress of infection, ATP release may result from the NLRP3 inflammasome response to COVID-19 infection (i) after virus spike protein interaction with the virus entry receptor ACE2, (ii) due to elevated level of Ang II observed in infected patients, or (iii) in response to activated ComC mediators [61]. Consequently, $\mathrm{P} 2 \mathrm{X} 7$ receptors are activated, increasing inflammatory responses as well as modulating RAAS-related pathways and $\mathrm{BBB}$ permeability, as we discuss in the following.

\section{$\mathrm{P} 2 \mathrm{X7}$ receptor role in inflammation}

The $\mathrm{P} 2 \mathrm{X} 7$ receptor is a trimeric ionotropic receptor that belongs to the $\mathrm{P} 2 \mathrm{X}$ family of purinergic receptors, presenting low affinity for ATP (EC $\mathrm{E}_{50}$ around $0.3-1.8 \mathrm{mM}$ ) and, under prolonged stimulation, can form pores allowing the passage of large hydrophilic molecules [62-64]. Activation of $\mathrm{P} 2 \mathrm{X} 7$ receptor elicits rapid $\mathrm{K}^{+}$efflux as well as $\mathrm{Ca}^{2+}$ and $\mathrm{Na}^{+}$influx, resulting in the stimulation of several intracellular intermediators, as PLC, PLA2, PKC, MAPK,
PI3K, ERK1/2 and p38, among others [65]. Consequently, $\mathrm{P} 2 \mathrm{X} 7$ receptor activation is associated with numerous cellular functions, as plasma membrane blebbing, phosphatidylserine exposure in the membrane, formation of ROS, interleukin secretion, cell death and proliferation $[65,66]$.

ATP concentration is present in the nanomolar range in extracellular space of healthy tissues [67]. Conversely, in a disease state as infection or brain disease, extracellular ATP levels largely increase and activate $\mathrm{P} 2 \mathrm{X} 7$ receptors [68-70]. Consequently, pore formation results in enhanced release of ATP and establishes a positive feedback in pathological conditions. In these circumstances, ATP may act as DAMP, which activates the nuclear transcription factor $N F-\kappa B$ resulting in expression upregulation of pro-IL-1 $\beta$ and proIL-18 and the NLRP3 protein [16, 71]. In addition, P2X7 receptor activation triggers $\mathrm{K}^{+}$efflux, a signal required for efficient NLRP3 inflammasome stimulation [72]. Consequently, there is an activation of caspase- 1 and maturation of IL-1 $\beta$ and IL-18, resulting in pro-inflammatory cytokine release $[16,20,52,71,73]$. The $\mathrm{P} 2 \mathrm{X} 7$ receptor is a major activator of the NLRP3 inflammasome in several cell types [16], including macrophages and microglial cells [72, 7476]. Moreover, $\mathrm{P} 2 \mathrm{X} 7$ receptor activation also promotes the release of other inflammatory mediators such as IL-6, TNF$\alpha$, CCL2, CCL3, and CXCL2 [77-80].

In fact, the role of $\mathrm{P} 2 \mathrm{X} 7$ receptor as a modulator of inflammatory response is well-established [16, 70]. It was already reported its capacity to modulate acute and chronic infection [81, 82], inflammatory diseases [82], sepsis [83, 84], neuropathic pain [85], and T-cell activation [86]. In addition, $\mathrm{P} 2 \mathrm{X} 7$ receptor expression deletion appears to be beneficial in case of acute lung injury, asthma, lung inflammation, and fibrosis [87-91]. Remarkably, P2X7 receptor activation increases neuroinflammatory responses, which have been associated with neurodegenerative diseases, psychiatric disorders and stroke [21, 92-95], as further discussed.

Cytokine storms have been reported in several viral infections [96], including SARS-CoV-2 [9, 97]. Patients infected with SARS-CoV-2 present elevated levels of IL-6, IL-10, IL-1 $\beta$, INF- $\gamma$, CCL2, TNF- $\alpha$, CXCL10, CCL7, IL-1 receptor antagonist and IL-2 receptor, supposedly associated with disease severity [9, 98-105]. Considering the $\mathrm{P} 2 \mathrm{X} 7$ receptor role in inflammation, its activation may be involved in the cytokine storm observed in COVID-19 by stimulating NLRP3 inflammasome, overshooting inflammation with extensive cytokine release, affecting coagulation and leading to diffuse lung edema and infiltration by immune cells and inflammatory cytokines [106]. As discussed by Di Virgilio et al. [106], many processes associated with lung impairment, as seen in COVID-19 patients, are mediated by $\mathrm{P} 2 \mathrm{X} 7$ receptors [16]. The massive ATP release following lung mononuclear phagocytes 
invasion by SARS-CoV-2 can activate $\mathrm{P} 2 \mathrm{X} 7$ receptors of antigen-presenting cells and macrophages, increasing cytokine, chemokine and ATP secretion [16]. In addition, P2X7 receptor knockout mice submitted to a model of lung fibrosis revealed reduced infiltration of inflammatory cells, cytokine release, apoptosis, and fibrosis, while P2X7 receptor agonists increased these deleterious processes [88, 107].

Therefore, we hypothesize that the $\mathrm{P} 2 \mathrm{X} 7$ receptor activation is involved in the cytokine storm and associated lung and brain inflammation caused by SARS-CoV-2 infection.

\section{$\mathrm{P} 2 \mathrm{X7}$ receptors and the renin-angiotensin system}

The P2X7 receptor, as a central player in inflammation, participates in viral infections. Exerting mostly proinflammatory roles [20], the P2X7 receptor is important for pathogen elimination [108], but on the other hand, its activation may be detrimental to the host due to the induction of exacerbated inflammatory responses. Protective roles of $\mathrm{P} 2 \mathrm{X} 7$ receptor activation have been described, for instance, against vesicular stomatitis virus, Newcastle disease virus, murine leukemia virus and HSV virus infections [108]. Controversially to the above-cited beneficial $\mathrm{P} 2 \mathrm{X} 7$ receptor-mediated viral elimination, this receptor was described to even facilitate virion release from HIV-infected macrophages in an exocytosis-dependent way [109]. Moreover, P2X7 receptor activation exacerbated inflammation, enhanced tissue damage, increased mortality, and worsened lung pathology involving P2X7 receptor expression or activation, such as observed in several other studies with e.g., influenza A virus [110] and adenovirus [111].

Importantly, the $\mathrm{P} 2 \mathrm{X} 7$ receptor triggers pathways related to the functioning of the RAAS, importantly implicated in COVID-19 pathology. RAAS mediates key events of the disease, including viral entry in the cell [112, 113], inflammation, and lung fibrosis [114]. The pressor axis of RAAS bases on Ang II actions through the activation of $\mathrm{AT}_{1} \mathrm{R} . \mathrm{ACE}$ is responsible for the cleavage of angiotensin I into Ang II, and Ang II levels are counterbalanced by the depressor axis that degrades Ang II into Ang 1,7 through ACE2 activity. Finally, Ang 1,7 activates MasR [115]. ACE2, independent from its enzymatic activity, serves as SARS-CoV-2 entry route in human cells, but as this enzyme is internalized following virus binding, its enzyme function is lost [6, 116]. Consequently, Ang 1,7 that would exert beneficial effects against CNS damage and neurological deficits [115] is not formed, prevailing Ang II actions mediated by the $\mathrm{AT}_{1} \mathrm{R}$ promoting fibrosis, lung injury, and importantly neuroinflammation [115].

In fact, the balance between the pressor and depressor axis of RAAS is implicated in neurodegenerative and psychiatric disorders, as carefully reviewed elsewhere
$[115,117]$. Briefly, components of the depressor axis correlate to enhanced cognition and cell survival in the brain, orchestrating antioxidant, and anti-inflammatory responses. In agreement, inhibition of the pressor axis attenuates cognitive deficits observed in aging, Alzheimer's disease, Parkinson's disease, vascular cognitive impairment and poststroke cognitive impairment [117].

Since the $\mathrm{P} 2 \mathrm{X} 7$ receptor is also involved in lung damage [87-89], neurodegenerative and psychiatric disorders [92, 95, 118], the hypothesis is reasonable that inhibition of this receptor might decrease pathological traits mediated by the RAAS pressor axis and protect against brain and lung injury in COVID-19 patients. Indeed, evidence demonstrates that $\mathrm{P} 2 \mathrm{X} 7$ receptor blockade prevents Ang IItriggered pro-inflammatory responses [119]. Furthermore, in rats with diabetic nephropathy, $\mathrm{P} 2 \mathrm{X} 7$ receptor expression decreased ACE activity and Ang II levels [120], which might increase ACE2 expression [43] and counteract SARS-CoV-2-induced inflammatory exacerbation.

Conciliating all these findings, we highlight that the blockade of $\mathrm{P} 2 \mathrm{X} 7$ receptors might prevent inflammatory exacerbation both, through its direct actions in inflammasome assembly and through RAAS modulation, avoiding deleterious actions of RAAS in several tissues, including the lung and the brain.

\section{P2X7 receptors in BBB permeability}

The $\mathrm{BBB}$ protects the nervous tissue from direct contact to the blood. Endothelial cells comprise the BBB and are highly selective in consequently filtering the content that is available to neurons [121]. Endothelial cells express high levels of ACE2, which is the main mediator of SARS-CoV-2 infection. The infection and death of these cells may disrupt the barrier and let both the virus and inflammation molecules to access the nervous system (Fig. 1C).

As previously mentioned, ATP acts as a DAMP and activates the $\mathrm{P} 2 \mathrm{X} 7$ receptor, which is largely expressed by endothelial cells and astrocytes/microglial cells, releasing pro-inflammatory cytokines and amplifying the immune response [122]. The opening of $\mathrm{P} 2 \mathrm{X} 7$ receptor channels leads to IL-1 $\beta$ production mainly through NLRP3 inflammasome activation [123], thus contributing to the disruption of the BBB. In this way, SARS-CoV-2 infection can disrupt the BBB by directly infecting and killing endothelial cells, as well as by triggering $\mathrm{P} 2 \mathrm{X} 7$ receptor signaling. In agreement, $\mathrm{P} 2 \mathrm{X} 7$ receptor antagonism protects against $\mathrm{BBB}$ disruption during intracerebral hemorrhage [124]. Moreover, disruption of the BBB due to other viral infections has already been proven to trigger long-term development of neurological disorders, such as Alzheimer's disease, depression, anxiety and multiple sclerosis [125-127]. 
Both intracerebral hemorrhage, against which the P2X7 receptor antagonist protects [124], and clots are responsible for the primary stroke in the brain [128]. COVID-19 patients are suffering acute cerebrovascular disorder and other correlated neurological symptoms as consequences of stroke or micro-strokes [24]. Stroke includes medical conditions that affect blood vessels of the brain, impairing cerebral circulation as consequence of damaged or deformed arteries (Fig. 2A). Diverse hospitals reported increasing levels of patients affected by stroke during SARS-CoV-2 infection [129, 130]. Klok and colleagues observed disturbing increases in the incidence of thrombotic complications in critically ill intensive care unit patients as high as $31 \%$ and recommended pharmacological prophylaxis against thrombosis [24].

The most recent hypothesis for the increased levels of strokes in COVID-19 patients is that hundreds of clots produced in the lungs due to excessive inflammation process may be transported into brain arteries, causing stroke by ischemia. Further, the virus can access the brain through the blood stream and infect BBB cells, as observed for other viruses [131]. Both ways can lead to increased inflammation due to hypoxia, increased acidification and release of DAMPs at the niche of the injury, disrupting the BBB and damaging the CNS and, thus, leading to the development of neuropsychiatric disorders.

\section{Neuropsychiatry and neurodegenerative disorders associated to COVID-19}

As already mentioned, inflammation is mediated by cytokines, chemokines, ROS and other bioactive molecules. These molecules act like DAMPs, signaling astro- and microgliosis. The first immune response to an insult in the nervous system is the activation of microglial cells of the M2 phenotype, which is involved in anti-inflammatory mechanisms for defense and injury repair [132]. However, the sustained activation of these cells induces the phenotypic change to the M1 type, involved in pro-apoptotic processes, production and release of cytokines and ROS that could induce neurodegeneration. In fact, neuroinflammation is closely related to neurodegenerative diseases, as Huntington's [133], Alzheimer's [134] and Parkinson's disease [135] and neuropsychiatric disorders, such as major depressive disorder, bipolar disorder and anxiety [136]. Since the CNS immune response is also modulated by peripheral components [137], we hypothesized that the cytokine storm induced by viral infection could stimulate neuroinflammation and neuronal death, facilitating the development of these diseases (Fig. 2B). Pathological inflammation may be induced by $\mathrm{P} 2 \mathrm{X} 7$ receptor activation, and its antagonism has been proposed as a therapeutic approach for COVID-19 treatment [106].
The role of the $\mathrm{P} 2 \mathrm{X} 7$ receptor in neuroinflammatory processes in neuropsychiatric and neurodegenerative diseases is widely studied [95, 118]. In neurodegenerative diseases, cell death is accompanied by neuroinflammatory processes and massive ATP release [138]. In animal models for neurodegeneration $\mathrm{P} 2 \mathrm{X} 7$ receptor antagonism exerted beneficial anti-inflammatory effects [138, 139], indicating that P2X7 receptor activation and subsequent neuroinflammation is tightly related to neurodegeneration worsening. Experimental evidence supports that viral infection may evoke neuronal death, encephalopathy, myelin destruction and juvenile Parkinson's disease development; however, these studies did not include coronaviruses [140]. These evidences indicate that viral infection facilitates neurodegenerative disease development, as Alzheimer's disease, Multiple Sclerosis and Parkinson's Disease [140]. In fact, murine coronavirus is used to induce encephalitis in mice with prominent demyelination and axonal damage. Based on observed pathophysiology and disease progression, this has been proposed as an animal model of multiple sclerosis [141].

Curiously, anosmia is one of the neurological symptoms reported by SARS-CoV-2 patients. It is worthwhile noting that olfactory impairment is an early predictor of Parkinson's disease development due to $\alpha$-synuclein aggregation in the olfactory bulb [142]. Although these symptoms might not be disease-related, studies show that $\alpha$-synuclein induces mitochondrial dysfunction and microglial activation caused by $\mathrm{P} 2 \mathrm{X} 7$ receptor stimulation [143, 144]. Further investigation of neural cell marker expression of COVID-19 patients could clarify, whether neuroinflammation is related to the observed anosmia.

Neuroinflammation and increased levels of ATP are observed in neuropsychiatry disorders, supposedly correlated with $\mathrm{P} 2 \mathrm{X} 7$ receptor activation $[118,145]$. Corroborating this hypothesis, antidepressant treatment decreased P2X7 receptor expression in the ventral hippocampus of stressed animals [146]. Moreover, the treatment with a selective $\mathrm{P} 2 \mathrm{X} 7$ receptor antagonist (A-804598) induced antidepressant-like effect associated with inflammasome stimulation [147] and BDNF signaling activation [148] in rodent hippocampus. In this context, we propose that the cytokine storm and cell death induced by SARS$\mathrm{CoV}-2$ infection results in $\mathrm{P} 2 \mathrm{X} 7$ receptor-mediated neuroinflammation, leading to the development of neuropsychiatry disorders. Noteworthy, the $\mathrm{P} 2 \mathrm{X} 7$ receptor antagonist JNJ-54175446 is undergoing clinical trials with treatment-resistant depressive patients (EudraCT number 2018-001884-21 at www.clinicaltrialsregister.eu).

As mentioned, a study with 714 patients with COVID-19 found a prevalence of self-reported post-traumatic stress disorder symptoms in $96.2 \%$ of them [149]. Another study with 114 patients reported that $34.7 \%$ of patients presented anxiety symptoms, while $28.5 \%$ of them displayed 
depression symptoms [150]. Moreover, COVID-19 related psychiatric symptoms (including anger, anxiety, suicidal ideas, hallucinations, insomnia, impaired memory, poor concentration, time disorientation, fear/panic, pressured speech, mood alterations, pessimistic thinking, crying spell and persecutory ideas) have been largely described during and after the occurrence of other respiratory pandemics, such as MERS [151] and SARS [152-159]. Further indication for psychiatric implications of coronaviruses infections came from a study of Okusaga et al. [160], who connected seropositivity for human coronavirus strain L63 with mood disorders and suicide attempts. The study could come to a limited conclusion, as it would need to be conducted with more control and coronavirus-serum positive volunteers. However, the authors of this study distinguished between two possible scenarios, which might be important for the understanding of neuronal effects of COVID-19: (1) the connection between depression and immune responses with possible pro-inflammatory interleukin overshooting, which may trigger oxidative stress and neuroinflammation as part of the causes of psychiatric disorders; and (2) viral infection acting as a form of stress. Dysregulated stress and neuroinflammatory responses might cause hypothalamic-pituitary-adrenal (HPA) axis dysfunction. Alterations in the HPA axis have been linked to mood diseases, and HPA activation has been connected with suicide. Hiroi et al. found hyperplastic adrenals in suicide victims, corroborating with such hypothesis [161]. In line, a small COVID-19 patients' study concluded that preexisting psychiatric disease patients reported mental symptom worsening following infection with the virus [162].

Noteworthy, gene knockout or pharmacological inhibition of $\mathrm{P} 2 \mathrm{X} 7$ receptors induced antidepressant-like behavior in mice exposed to stress, accompanied by HPA axis restoration [163, 164]. This axis is also activated for counteracting tissue damage, evoked by cytokine storms, in SARS-CoV-2 infection, as previously reviewed [165]. Thus, the HPA axis might provide a connection between coronaviruses and psychiatric disorders. Noteworthy, such mechanism would explain the possible propensity for the development of mood disorders triggered by COVID-19 infection as well as raise the hypothesis that mood disorder patients might be more prone to severe COVID-19 disease development. These patients already carry augmented inflammation patterns, such as systemic inflammation, or suffer from a cytokine storm [166] and show enhanced $\mathrm{P} 2 \mathrm{X} 7$ receptor expression, as previously discussed. However, a wide variety of responses to SARS-CoV-2 infection are not yet understood. Further studies are needed to elucidate genetic and environmental factors that could affect individual vulnerability to COVID-19 infection.
Finally, increasing VEGF concentrations, which recruit inflammatory cells into the brain and sustain neuroinflammation, have been named as target for COVID-19 treatment [167]. The COVID-19 entry receptor ACE2 activates RAAS for neuroinflammation and VEGF synthesis by Ang II binding to $\mathrm{AT}_{1} \mathrm{R}$ (reviewed in ref. [167]). Besides ACE2, aberrant $\mathrm{P} 2 \mathrm{X} 7$ receptor activation also induces VEGF release and signaling in the brain [168]. Thus, although VEGF involvement in major depressive disorder is controversially discussed $[169,170]$, this growth factor could be involved in the connection between COVID-19, major depressive disorder and purinergic signaling.

\section{Conclusion}

Several lines of evidence have raised the possibility of neuroinvasion by SARS-CoV-2 (Fig. 1), which may cause short- or long-term impairment of the CNS. The main mechanism involved in this scenario is neuroinflammation, a critical process in psychiatric and neurodegenerative disease development. SARS-CoV-2 infection induces a cytokine storm that could trigger and/or worse neuroinflammatory processes. Patients with mental disorders associated to neuroimmune activation such as depression, Parkinson's or Alzheimer's disease may also present increased susceptibility to SARS-CoV-2 infection and/or severe disease development. Neuroimmune response hyperstimulation observed during viral infection and in mental disorders may be mediated by $\mathrm{P} 2 \mathrm{X} 7$ receptor activation (Fig. 2). In view of that, we suggest $\mathrm{P} 2 \mathrm{X} 7$ receptor as a key mediator of the neuroinflammatory process as a possible consequence of SARS-CoV-2 infection. In this context, $\mathrm{P} 2 \mathrm{X} 7$ receptor antagonism could be a promising strategy to avoid and treat psychiatric disorders and neurodegenerative diseases of COVID-19 patients.

Acknowledgements HU and CL acknowledge grant support from the São Paulo Research Foundation (FAPESP, Project No. 2015/19128-2 and 2018/07366-4). HU acknowledges the National Council for Scientific and Technological Development for fellowship support (CNPq, Project No. 306392/2017-8). MZR work was supported by the NIH grant 2R01 DK074720, the Stella and Henry Hoenig Endowment. DER, AO-G, and TG are grateful for postdoctoral fellowships granted by FAPESP (Project No. 2018/17504-5, 2019/26852-0, and 2015/ 13345-1-PD, respectively). VFA-S thanks CNPq for a doctoral fellowship (Project No. 141264/2017-9). RA is grateful for a doctoral fellowship from FAPESP (Project No. 2019/24553-5) and JB for the doctoral fellowship granted by CNPq (Project No. 142137/2019-7).

\section{Compliance with ethical standards}

Conflict of interest The authors declare that they have no conflict of interest. 
Publisher's note Springer Nature remains neutral with regard to jurisdictional claims in published maps and institutional affiliations.

\section{References}

1. Walls AC, Park Y-J, Tortorici MA, Wall A, McGuire AT, Veesler D. Structure, function, and antigenicity of the SARSCoV-2 spike glycoprotein. Cell. 2020;181:281-92.

2. Letko M, Marzi A, Munster V. Functional assessment of cell entry and receptor usage for SARS-CoV-2 and other lineage B betacoronaviruses. Nat Microbiol. 2020;5:562-9.

3. Wang K, Chen W, Zhou Y-S, Lian J-Q, Zhang Z, Du P, et al. SARS-CoV-2 invades host cells via a novel route: CD147-spike protein. 2020. https://doi.org/10.1101/2020.03.14.988345.

4. Ulrich H, Pillat MM. CD147 as a target for COVID-19 treatment: suggested effects of azithromycin and stem cell engagement. Stem Cell Rev Rep. 2020;2020:1-7.

5. Hoffmann M, Kleine-Weber H, Schroeder S, Krüger N, Herrler $\mathrm{T}$, Erichsen $\mathrm{S}$, et al. SARS-CoV-2 cell entry depends on ACE2 and TMPRSS 2 and is blocked by a clinically proven protease inhibitor. Cell. 2020;181:271-80.e8.

6. Ou X, Liu Y, Lei X, Li P, Mi D, Ren L, et al. Characterization of spike glycoprotein of SARS-CoV-2 on virus entry and its immune cross-reactivity with SARS-CoV. Nat Commun. 2020;11:1620.

7. Ratajczak J, Wysoczynski M, Hayek F, Janowska-Wieczorek A, Ratajczak MZ. Membrane-derived microvesicles: Important and underappreciated mediators of cell-to-cell communication. Leukemia. 2006;20:1487-95.

8. Rozmyslowicz T, Majka M, Kijowski J, Murphy SL, Conover DO, Poncz $\mathrm{M}$, et al. Platelet- and megakaryocyte-derived microparticles transfer CXCR4 receptor to CXCR4-null cells and make them susceptible to infection by X4-HIV. AIDS. 2003; 17:33-42

9. Sun X, Wang T, Cai D, Hu Z, Chen J, Liao H, et al. Cytokine storm intervention in the early stages of COVID-19 pneumonia. Cytokine Growth Factor Rev. 2020;53:38-42.

10. Zubair AS, McAlpine LS, Gardin T, Farhadian S, Kuruvilla DE, Spudich H. Neuropathogenesis and neurologic manifestations of the coronaviruses in the age of coronavirus disease 2019: a review. JAMA Neurol. 2020;77:1018-27.

11. Gu J, Gong E, Zhang B, Zheng J, Gao Z, Zhong Y, et al. Multiple organ infection and the pathogenesis of SARS. J Exp Med. 2005;202:415-24.

12. Politi LS, Salsano E, Grimaldi M. Magnetic resonance imaging alteration of the brain in a patient with coronavirus disease 2019 (COVID-19) and anosmia. JAMA Neurol. 2020;77:1028-9.

13. Poyiadji N, Shahin G, Noujaim D, Stone M, Patel S, Griffith B. COVID-19-associated acute hemorrhagic necrotizing encephalopathy: CT and MRI features. Radiology. 2020;296:E119-20.

14. Reichard R, Kashani K, Boire N, Constantopoulos E, Guo Y, Lucchinetti C. Neuropathology of COVID-19: a spectrum of vascular and acute disseminated encephalomyelitis (ADEM)-like pathology. Acta Neuropathol. 2020;140:1-6.

15. Ferro JM, Caeiro L, Figueira ML. Neuropsychiatric sequelae of stroke. Nat Rev Neurol. 2016;12:269-80.

16. Di Virgilio F, Dal Ben D, Sarti AC, Giuliani AL, Falzoni S. The $\mathrm{P} 2 \mathrm{X} 7$ receptor in infection and inflammation. Immunity. 2017;47:15-31.

17. Ratajczak MZ, Mack A, Bujko K, Domingues A, Pedziwiatr D, Kucia M, et al. ATP-Nlrp3 inflammasome-complement cascade axis in sterile brain inflammation in psychiatric patients and its impact on stem cell trafficking. Stem Cell Rev Rep. 2019;15:497-505.
18. Ratajczak MZ, Bujko K, Cymer M, Thapa A, Adamiak M, Ratajczak J, et al. The Nlrp3 inflammasome as a "rising star" in studies of normal and malignant hematopoiesis. Leukemia. 2020;34:1512-23.

19. Sluyter R. The $\mathrm{P} 2 \mathrm{X} 7$ receptor. In: Atassi M, editor. Protein reviews. Advances in experimental medicine and biology. Singapore: Springer; 2017. p. 17-53.

20. Adinolfi E, Giuliani AL, De Marchi E, Pegoraro A, Orioli E, Di Virgilio F. The P2X7 receptor: a main player in inflammation. Biochem Pharmacol. 2018;151:234-44.

21. Sperlágh B, Illes P. P2X7 receptor: An emerging target in central nervous system diseases. Trends Pharm Sci. 2014;35:537-47.

22. Pezzini A, Padovani A. Lifting the mask on neurological manifestations of COVID-19. Nat Rev Neurol. 2020;16:636-44.

23. Klok FA, Kruip MJHA, van der Meer NJM, Arbous MS, Gommers DAMPJ, Kant KM, et al. Incidence of thrombotic complications in critically ill ICU patients with COVID-19. Thromb Res. 2020;191:145-7.

24. Butowt R, Bilinska K. SARS-CoV-2: olfaction, brain infection, and the urgent need for clinical samples allowing earlier virus detection. ACS Chem Neurosci. 2020;11:1200-3.

25. Puelles VG, Lütgehetmann M, Lindenmeyer MT, Sperhake JP, Wong MN, Allweiss L, et al. Multiorgan and renal tropism of SARS-CoV-2 [letter]. N Engl J Med. 2020;383:590-92.

26. Song E, Zhang C, Israelow B, Lu-Culligan A, Prado AV, Skriabine S, et al. Neuroinvasion of SARS-CoV-2 in human and mouse brain. 2020. https://doi.org/10.1101/2020.06.25. 169946.

27. Gomes IC, Karmirian K, Oliveira J, Pedrosa C, Rosman FC, Chimelli L, et al. SARS-CoV-2 infection in the central nervous system of a 1-year-old infant submitted to complete autopsy. 2020:2020090297. https://doi.org/10.20944/preprints202009. 0297.v1.

28. Paniz-Mondolfi A, Bryce C, Grimes Z, Gordon RE, Reidy J, Lednicky J, et al. Central nervous system involvement by severe acute respiratory syndrome coronavirus-2 (SARS-CoV-2). J Med Virol. 2020;92:699-702.

29. Yarlagadda A, Alfson E, Clayton AH. The blood-brain barrier and the role of cytokines in neuropsychiatry. Psychiatry. 2009;6:18-22.

30. Pan W, Stone KP, Hsuchou H, Manda VK, Zhang Y, Kastin AJ. Cytokine signaling modulates blood-brain barrier function. Curr Pharm Des. 2011;17:3729-40.

31. Spindler KR, Hsu TH. Viral disruption of the blood-brain barrier. Trends Microbiol. 2012;20:282-90.

32. Li YC, Bai WZ, Hashikawa T. The neuroinvasive potential of SARS-CoV2 may play a role in the respiratory failure of COVID-19 patients. J Med Virol. 2020;92:552-5.

33. Fodoulian L, Tuberosa J, Rossier D, Landis B, Carleton A, Rodriguez I. SARS-CoV-2 receptor and entry genes are expressed by sustentacular cells in the human olfactory neuroepithelium. 2020. https://doi.org/10.1101/2020.03.31.013268.

34. Brann DH, Tsukahara T, Weinreb C, Lipovsek M, Van den Berge K, Gong B, et al. Non-neuronal expression of SARS-CoV2 entry genes in the olfactory system suggests mechanisms underlying COVID-19-associated anosmia. Sci Adv. 2020;6: eabc5801.

35. McCray PB, Pewe L, Wohlford-Lenane C, Hickey M, Manzel L, Shi L, et al. Lethal infection of K18-hACE2 mice infected with severe acute respiratory syndrome coronavirus. J Virol. 2007;81:813-21.

36. Jacomy H, Talbot PJ. Vacuolating encephalitis in mice infected by human coronavirus OC43. Virology. 2003;315:20-33.

37. Li K, Wohlford-Lenane C, Perlman S, Zhao J, Jewell AK, Reznikov LR, et al. Middle east respiratory syndrome coronavirus causes multiple organ damage and lethal disease in 
mice transgenic for human dipeptidyl peptidase 4. J Infect Dis. 2016;213:712-22.

38. Xu Z, Shi L, Wang Y, Zhang J, Huang L, Zhang C, et al. Pathological findings of COVID-19 associated with acute respiratory distress syndrome. Lancet Respir Med. 2020;8:420-2.

39. Bhatia M, Zemans RL, Jeyaseelan S. Role of chemokines in the pathogenesis of acute lung injury. Am J Respir Cell Mol Biol. 2012;46:566-72.

40. Dunkelberger JR, Song WC. Complement and its role in innate and adaptive immune responses. Cell Res. 2010;20:34-50.

41. Swanson KV, Deng M, Ting JP. The NLRP3 inflammasome: molecular activation and regulation to therapeutics. Nat Rev Immunol. 2019;19:477-89.

42. Bertheloot D, Latz E. HMGB1, IL-1alpha, IL-33 and S100 proteins: dual-function alarmins. Cell Mol Immunol. 2017;14:43-64.

43. Kai H, Kai M. Interactions of coronaviruses with ACE2, angiotensin II, and RAS inhibitors-lessons from available evidence and insights into COVID-19. Hypertens Res. 2020;43:648-54.

44. Albalawi F, Lu W, Beckel JM, Lim JC, McCaughey SA, Mitchell $\mathrm{CH}$. The P2X7 receptor primes IL-1beta and the NLRP3 inflammasome in astrocytes exposed to mechanical strain. Front Cell Neurosci. 2017;11:227.

45. Nascimento JHP, Gomes BF, de O, Do Carmo Júnior PR, Petriz JLF, Rizk SI, et al. Covid-19 and hypercoagulable state: a new therapeutic perspective. Arq Bras Cardiol. 2020;114:829-33.

46. Ratajczak MZ, Pedziwiatr D, Cymer M, Kucia M, KucharskaMazur J, Samochowiec J. Sterile inflammation of brain, due to activation of innate immunity, as a culprit in psychiatric disorders. Front Psychiatry. 2018;9:60.

47. Burnstock G, Kennedy C. P2X receptors in health and disease. In: Advances in pharmacology, vol. 61. Academic Press Inc; 2011. p. 333-72.

48. Janks L, Sprague RS, Egan TM. ATP-gated P2X7 receptors require chloride channels to promote inflammation in human macrophages. J Immunol. 2019;202:883-98.

49. Chen Z, Jin N, Narasaraju T, Chen J, McFarland LR, Scott M, et al. Identification of two novel markers for alveolar epithelial type I and II cells. Biochem Biophys Res Commun. 2004;319:774-80.

50. Kaczmarek-Hajek K, Zhang J, Kopp R, Grosche A, Rissiek B, Saul A, et al. Re-evaluation of neuronal P2X7 expression using novel mouse models and a P2X7-specific nanobody. Elife. 2018;7:1-29.

51. Metzger MW, Walser SM, Aprile-Garcia F, Dedic N, Chen A, Holsboer F, et al. Genetically dissecting P2rx7 expression within the central nervous system using conditional humanized mice. Purinergic Signal. 2017;13:153-70.

52. He Y, Taylor N, Fourgeaud L, Bhattacharya A. The role of microglial P2X7: modulation of cell death and cytokine release. J Neuroinflammation. 2017;14:135.

53. Sperlágh B, Köfalvi A, Deuchars J, Atkinson L, Milligan CJ, Buckley NJ, et al. Involvement of P2X7 receptors in the regulation of neurotransmitter release in the rat hippocampus. $\mathrm{J}$ Neurochem. 2002;81:1196-211.

54. Wirkner K, Köfalvi A, Fischer W, Günther A, Franke H, GrögerArndt $\mathrm{H}$, et al. Supersensitivity of $\mathrm{P} 2 \mathrm{X} 7$ receptors in cerebrocortical cell cultures after in vitro ischemia. J Neurochem. 2005;95:1421-37.

55. Yu Y, Ugawa $S$, Ueda $T$, Ishida $Y$, Inoue $K$, Kyaw Nyunt $A$, et al. Cellular localization of P2X7 receptor mRNA in the rat brain. Brain Res. 2008;1194:45-55.

56. Anderson CM, Nedergaard M. Emerging challenges of assigning $\mathrm{P} 2 \mathrm{X} 7$ receptor function and immunoreactivity in neurons. Trends Neurosci. 2006;29:257-62.
57. Illes P, Khan TM, Rubini P. Neuronal P2X7 receptors revisited: do they really exist? J Neurosci. 2017;37:7049-62.

58. Khan MT, Deussing J, Tang Y, Illes P. Astrocytic rather than neuronal P2X7 receptors modulate the function of the trisynaptic network in the rodent hippocampus. Brain Res Bull. 2018;151:164-73.

59. Fischer W, Appelt K, Grohmann M, Franke H, Nörenberg W, Illes $\mathrm{P}$. Increase of intracellular $\mathrm{Ca} 2+$ by $\mathrm{P} 2 \mathrm{X}$ and $\mathrm{P} 2 \mathrm{Y}$ receptorsubtypes in cultured cortical astroglia of the rat. Neuroscience. 2009;160:767-83.

60. Rubini P, Pagel G, Mehri S, Marquardt P, Riedel T, Illes P. Functional $\mathrm{P} 2 \mathrm{X} 7$ receptors at cultured hippocampal astrocytes but not neurons. Naunyn Schmiedebergs Arch Pharm. 2014;387:943-54.

61. Ratajczak MZ, Kucia M. SARS-CoV-2 infection and overactivation of Nlrp3 inflammasome as a trigger of cytokine "storm" and risk factor for damage of hematopoietic stem cells. Leukemia. 2020;34:1726-9.

62. Chessell IP, Michel AD, Humphrey PPA. Properties of the poreforming P2X7 purinoceptor in mouse NTW8 microglial cells. Br J Pharm. 1997;121:1429-37.

63. Chessell IP, Michel AD, Humphrey PPA. Effects of antagonists at the human recombinant $\mathrm{P} 2 \mathrm{X} 7$ receptor. $\mathrm{Br} \mathrm{J}$ Pharm. 1998;124:1314-20.

64. Di Virgilio F, Schmalzing G, Markwardt F. The elusive P2X7 macropore. Trends Cell Biol. 2018;28:392-404.

65. Kopp R, Krautloher A, Ramírez-Fernández A, Nicke A. P2X7 interactions and signaling-making head or tail of it. Front Mol Neurosci. 2019;12:1-25.

66. Sluyter R, Stokes L. Significance of $\mathrm{p} 2 \mathrm{x} 7$ receptor variants to human health and disease. Recent Pat DNA Gene Seq. 2011;5:41-54.

67. Falzoni S, Donvito G, Di Virgilio F. Detecting adenosine triphosphate in the pericellular space. Interface Focus. 2013;3:20120101.

68. Pellegatti P, Raffaghello L, Bianchi G, Piccardi F, Pistoia V, Di Virgilio F. Increased level of extracellular ATP at tumor sites: in vivo imaging with plasma membrane luciferase. PLoS ONE. 2008:3:e2599.

69. Wilhelm K, Ganesan J, Grimm M, Beilhack A, Krempl CD, Sorichter S, et al. Graft-versus-host disease is enhanced by extracellular ATP activating P2X7R. Nat Med. 2010;16:1434-9.

70. Barberà-Cremades M, Baroja-Mazo A, Gomez AI, Machado F, Di Virgilio F, Pelegrín P. P2X7 receptor-stimulation causes fever via PGE2 and IL-1 $\beta$ release. FASEB J. 2012;26:2951-62.

71. Jo EK, Kim JK, Shin DM, Sasakawa C. Molecular mechanisms regulating NLRP3 inflammasome activation. Cell Mol Immunol. 2016;13:148-59.

72. Gustin A, Kirchmeyer M, Koncina E, Felten P, Losciuto S, Heurtaux T, et al. NLRP3 inflammasome is expressed and functional in mouse brain microglia but not in astrocytes. PLoS ONE. 2015;10:1-19.

73. Bhattacharya A, Jones DNC. Emerging role of the P2X7NLRP3-IL1 $\beta$ pathway in mood disorders. Psychoneuroendocrinology. 2018;98:95-100.

74. Perregaux DG, Gabel CA. Human monocyte stimulus-coupled IL-1 $\beta$ posttranslational processing: modulation via monovalent cations. Am J Physiol - Cell Physiol. 1998;275:C1538-47.

75. Qu Y, Franchi L, Nunez G, Dubyak GR. Nonclassical IL-1 beta secretion stimulated by $\mathrm{P} 2 \mathrm{X} 7$ receptors is dependent on inflammasome activation and correlated with exosome release in murine macrophages. J Immunol. 2007;179:1913-25.

76. Bianco F, Pravettoni E, Colombo A, Schenk U, Möller T, Matteoli M, et al. Astrocyte-derived ATP induces vesicle shedding and IL-1 $\beta$ release from microglia. J Immunol. 2005;174:7268-77. 
77. Kataoka A, Tozaki-Saitoh H, Koga Y, Tsuda M, Inoue K. Activation of $\mathrm{P} 2 \mathrm{X} 7$ receptors induces CCL3 production in microglial cells through transcription factor NFAT. J Neurochem. 2009;108:115-25.

78. Suzuki T, Hide I, Ido K, Kohsaka S, Inoue K, Nakata Y. Production and release of neuroprotective tumor necrosis factor by P2X 7 receptor-activated microglia. J Neurosci. 2004;24:1-7.

79. Shieh CH, Heinrich A, Serchov T, van Calker D, Biber K. P2X7dependent, but differentially regulated release of IL-6, CCL2, and TNF- $\alpha$ in cultured mouse microglia. Glia. 2014;62:592-607.

80. Shiratori M, Tozaki-Saitoh H, Yoshitake M, Tsuda M, Inoue K. $\mathrm{P} 2 \mathrm{X} 7$ receptor activation induces CXCL2 production in microglia through NFAT and PKC/MAPK pathways. J Neurochem. 2010;114:810-9.

81. Morandini A, Savio L, Coutinho-Silva R. The role of $\mathrm{p} 2 \times 7$ receptor in infectious inflammatory diseases and the influence of ectonucleotidases. Biomed J. 2014;37:169-77.

82. Savio LEB, Mello P de A, da Silva CG, Coutinho-Silva R. The P2X7 receptor in inflammatory diseases: angel or demon? Front Pharmacol. 2018;9:1-31.

83. Martínez-García J, Martínez-Banaclocha H, Angosto-Bazarra D, De Torre-Minguela C, Baroja-Mazo A, Alarcón-Vila C, et al. $\mathrm{P} 2 \mathrm{X} 7$ receptor induces mitochondrial failure in monocytes and compromises NLRP3 inflammasome activation during sepsis. Nat Commun. 2019;10:1-14.

84. Savio LEB, Juste Andrade MG, de Andrade Mello P, Teixeira Santana P, Cristina Abreu Moreira-Souza A, Kolling J, et al. $\mathrm{P} 2 \mathrm{X} 7$ receptor signaling contributes to sepsis-associated brain dysfunction. Mol Neurobiol. 2017;54:6459-70.

85. Chessell IP, Hatcher JP, Bountra C, Michel AD, Hughes JP, Green P, et al. Disruption of the P2X7 purinoceptor gene abolishes chronic inflammatory and neuropathic pain. Pain. 2005; 114:386-96.

86. Yip L, Woehrle T, Corriden R, Hirsh M, Chen Y, Inoue Y, et al. Autocrine regulation of T-cell activation by ATP release and P2X7 receptors. FASEB J. 2009;23:1685-93.

87. Galam L, Rajan A, Failla A, Soundararajan R, Lockey RF, Kolliputi N. Deletion of P2X7 attenuates hyperoxia-induced acute lung injury via inflammasome suppression. Am J Physiol Lung Cell Mol Physiol. 2016;310:572-81.

88. Duan L, Hu Ghuang, Li Yjin, Zhang Cliang, Jiang M. P2X7 receptor is involved in lung injuries induced by ischemiareperfusion in pulmonary arterial hypertension rats. Mol Immunol. 2018;101:409-18.

89. Riteau N, Gasse P, Fauconnier L, Gombault A, Couegnat M, Fick L, et al. Extracellular ATP is a danger signal activating $\mathrm{P} 2 \mathrm{X} 7$ receptor in lung inflammation and fibrosis. Am J Respir Crit Care Med. 2010;182:774-83.

90. Wang S, Zhao J, Wang H, Liang Y, Yang N, Huang Y. Blockage of P2X7 attenuates acute lung injury in mice by inhibiting NLRP3 inflammasome. Int Immunopharmacol. 2015;27:38-45.

91. Li R, Wang J, Li R, Zhu F, Xu W, Zha G, et al. ATP/P2X7NLRP3 axis of dendritic cells participates in the regulation of airway inflammation and hyper-responsiveness in asthma by mediating HMGB1 expression and secretion. Exp Cell Res. 2018;366:1-15.

92. Cheffer A, Castillo AR, Corrêa-Velloso JC, Gonçalves MCB, Naaldijk Y, Nascimento IC, et al. Purinergic system in psychiatric diseases. Mol Psychiatry. 2018;23:94-106.

93. Bhattacharya A, Biber K. The microglial ATP-gated ion channel P2X7 as a CNS drug target. Glia. 2016;64:1772-87.

94. Burnstock G. Purinergic signalling and neurological diseases: an update. CNS Neurol Disord - Drug Targets. 2017;16:257-65.

95. Andrejew R, Oliveira-Giacomelli Á, Ribeiro DE, Glaser T, Arnaud-Sampaio VF, Lameu C, et al. The P2X7 receptor: central hub of brain diseases. Front Mol Neurosci. 2020;13:124.
96. Tisoncik JR, Korth MJ, Simmons CP, Farrar J, Martin TR, Katze MG. Into the eye of the cytokine storm. Microbiol Mol Biol Rev. 2012;76:16-32.

97. Ye Q, Wang B, Mao J. The pathogenesis and treatment of the "Cytokine Storm" in COVID-19. J Infect. 2020;80:607-13.

98. Huang C, Wang Y, Li X, Ren L, Zhao J, Hu Y, et al. Clinical features of patients infected with 2019 novel coronavirus in Wuhan, China. Lancet. 2020;395:497-506.

99. Yang Y, Shen C, Li J, Yuan J, Wei J, Huang F, et al. Plasma IP10 and MCP-3 levels are highly associated with disease severity and predict the progression of COVID-19. J Allergy Clin Immunol. 2020;146:119-27.

100. Pedersen SF, Ho YC. SARS-CoV-2: a storm is raging. J Clin Invest. 2020;130:2202-5.

101. Chen G, Wu D, Guo W, Cao Y, Huang D, Wang H, et al. Clinical and immunological features of severe and moderate coronavirus disease 2019. J Clin Invest. 2020;130:2620-9.

102. Qin C, Zhou L, Hu Z, Zhang S, Yang S, Tao Y, et al. Dysregulation of immune response in patients With COVID-19 in Wuhan, China. Clin Infect Dis. 2020;71:762-8.

103. Gao Y, Li T, Han M, Li X, Wu D, Xu Y, et al. Diagnostic utility of clinical laboratory data determinations for patients with the severe COVID-19. J Med Virol. 2020;92:791-6.

104. Liu T, Zhang J, Yang Y, Ma H, Li Z, Zhang J, et al. The role of interleukin-6 in monitoring severe case of coronavirus disease 2019. EMBO Mol Med. 2020;12:e12421.

105. Wang Z, Yang B, Li Q, Wen L, Zhang R. Clinical features of 69 cases with coronavirus disease 2019 in Wuhan, China. Clin Infect Dis. 2020;71:769-77.

106. Di Virgilio F, Tang Y, Sarti AC, Rossato M. A rationale for targeting the $\mathrm{P} 2 \mathrm{X} 7$ receptor in Coronavirus disease 19 (Covid19). Br J Pharmacol. 2020;177:4990-94.

107. Monção-Ribeiro LC, Faffe DS, Santana PT, Vieira FS, da Graça CLAL, Marques-da-Silva C, et al. P2X7 receptor modulates inflammatory and functional pulmonary changes induced by silica. PLoS ONE. 2014;9:e110185.

108. Zhang $\mathrm{C}, \mathrm{He} \mathrm{H}$, Wang L, Zhang $\mathrm{N}$, Huang $\mathrm{H}$, Xiong Q, et al. Virus-triggered ATP release limits viral replication through facilitating IFN- $\beta$ production in a P2X7-dependent manner. $\mathrm{J}$ Immunol. 2017;199:1372-81.

109. Graziano F, Desdouits M, Garzetti L, Podini P, Alfano M, Rubartelli A, et al. Extracellular ATP induces the rapid release of HIV-1 from virus containing compartments of human macrophages. Proc Natl Acad Sci U S A. 2015;112:E3265-73.

110. Leyva-Grado VH, Ermler ME, Schotsaert M, Gonzalez MG, Gillespie V, Lim JK, et al. Contribution of the purinergic receptor $\mathrm{P} 2 \mathrm{X} 7$ to development of lung immunopathology during influenza virus infection. MBio. 2017;8:1-15.

111. Lee BH, Hwang DM, Palaniyar N, Grinstein S, Philpott DJ, Hu J. Activation of P2X(7) receptor by ATP plays an important role in regulating inflammatory responses during acute viral infection. PLoS ONE. 2012;7:e35812.

112. Zhang H, Penninger JM, Li Y, Zhong N, Slutsky AS. Angiotensin-converting enzyme 2 (ACE2) as a SARS-CoV-2 receptor: molecular mechanisms and potential therapeutic target. Intensive Care Med. 2020;46:586-90.

113. Pillat MM, Krüger A, Guimarães LMF, Lameu C, de Souza EE, Wrenger $\mathrm{C}$, et al. Insights in chloroquine action: perspectives and implications in Malaria and COVID-19. Cytom Part A. 2020;97:872-81.

114. Wang J, Chen L, Chen B, Meliton A, Liu SQ, Shi Y, et al. Chronic activation of the renin-angiotensin system induces lung fibrosis. Sci Rep. 2015;5:15561.

115. Gironacci MM, Vicario A, Cerezo G, Silva MG. The depressor axis of the renin-angiotensin system and brain disorders: A translational approach. Clin Sci. 2018;132:1021-38. 
116. Gheblawi M, Wang K, Viveiros A, Nguyen Q, Zhong JC, Turner $\mathrm{AJ}$, et al. Angiotensin-converting enzyme 2: SARS-CoV-2 receptor and regulator of the renin-angiotensin system: celebrating the 20th anniversary of the discovery of ACE2. Circ Res. 2020;126:1456-74.

117. Jackson L, Eldahshan W, Fagan SC, Ergul A. Within the brain: the renin angiotensin system. Int J Mol Sci. 2018;19:876.

118. Ribeiro DE, Roncalho AL, Glaser T, Ulrich H, Wegener G, Joca S. P2X7 receptor signaling in stress and depression. Int J Mol Sci. 2019;20:2778.

119. Bautista-Pérez R, Pérez-Méndez O, Cano-Martínez A, Pacheco U, Santamaría J, Rodríguez-Iturbe FRB, et al. The role of P2X7 purinergic receptors in the renal inflammation associated with angiotensin II-induced hypertension. Int J Mol Sci. 2020;21: E4041.

120. Nascimento M, Punaro GR, Serralha RS, Lima DY, Mouro MG, Oliveira LCG, et al. Inhibition of the P2X7 receptor improves renal function via renin-angiotensin system and nitric oxide on diabetic nephropathy in rats. Life Sci. 2020;251:117640.

121. Daneman R, Prat A. The blood-brain barrier. Cold Spring Harb Perspect Biol. 2015;7:a020412.

122. Yang F, Zhao K, Zhang X, Zhang J, Xu B. ATP induces disruption of tight junction proteins via IL-1 beta-dependent MMP9 activation of human blood-brain barrier in vitro. Neural Plast. 2016;2016:8928530.

123. Giuliani AL, Sarti AC, Falzoni S, Di Virgilio F. The P2X7 receptor-interleukin-1 liaison. Front Pharm. 2017;8:123.

124. Zhao H, Zhang X, Dai Z, Feng Y, Li Q, Zhang JH, et al. P2X7 receptor suppression preserves blood-brain barrier through inhibiting RhoA activation after experimental intracerebral hemorrhage in rats. Sci Rep. 2016;6:23286.

125. Ortiz GG, Pacheco-Moises FP, Macias-Islas MA, FloresAlvarado LJ, Mireles-Ramirez MA, Gonzalez-Renovato ED, et al. Role of the blood-brain barrier in multiple sclerosis. Arch Med Res. 2014;45:687-97.

126. Erickson MA, Banks WA. Blood-brain barrier dysfunction as a cause and consequence of Alzheimer's disease. J Cereb Blood Flow Metab. 2013;33:1500-13.

127. Dudek KA, Dion-Albert L, Lebel M, LeClair K, Labrecque S, Tuck E, et al. Molecular adaptations of the blood-brain barrier promote stress resilience vs. Depression Proc Natl Acad Sci U S A. 2020;117:3326-36.

128. Avula A, Nalleballe K, Narula N, Sapozhnikov S, Dandu V, Toom S, et al. COVID-19 presenting as stroke. Brain Behav Immun. 2020;87:115-9.

129. Khot UN, Reimer AP, Brown A, Hustey FM, Hussain MS, Kapadia SR, et al. Impact of COVID-19 pandemic on critical care transfers for ST-elevation myocardial infarction, stroke, and aortic emergencies. Circ Cardiovasc Qual Outcomes. 2020;13: e006938.

130. Wang H, Tang X, Fan H, Luo Y, Song Y, Xu Y, et al. Potential mechanisms of hemorrhagic stroke in elderly COVID-19 patients. Aging. 2020;12:10022-34.

131. Keep RF, Zhou N, Xiang J, Andjelkovic AV, Hua Y, Xi G. Vascular disruption and blood-brain barrier dysfunction in intracerebral hemorrhage. Fluids Barriers CNS. 2014;11:1-13.

132. Tang Y, Le W. Differential Roles of M1 and M2 microglia in neurodegenerative diseases. Mol Neurobiol. 2016;53:1181-94.

133. Lois C, González I, Izquierdo-García D, Zürcher NR, Wilkens P, Loggia ML, et al. Neuroinflammation in Huntington's disease: new Insights with 11C-PBR28 PET/MRI. ACS Chem Neurosci. 2018;9:2563-71.

134. Heneka MT, O’Banion MK, Terwel D, Kummer MP. Neuroinflammatory processes in Alzheimer's disease. J Neural Transm. 2010;117:919-47.
135. Troncoso-Escudero P, Parra A, Nassif M, Vidal RL. Outside in: unraveling the role of neuroinflammation in the progression of Parkinson's disease. Front Neurol. 2018;9:860.

136. Radtke FA, Chapman G, Hall J, Syed YA. Modulating neuroinflammation to treat neuropsychiatric disorders. Biomed Res Int. 2017;2017:5071786.

137. Sankowski R, Mader S, Valdés-Ferrer SI. Systemic inflammation and the brain: novel roles of genetic, molecular, and environmental cues as drivers of neurodegeneration. Front Cell Neurosci. 2015;9:98

138. Oliveira-Giacomelli Á, Naaldijk Y, Sardá-Arroyo L, Gonçalves MCB, Corrêa-Velloso J, Pillat MM, et al. Purinergic receptors in neurological diseases with motor symptoms: targets for therapy. Front Pharm. 2018;9:325.

139. Oliveira-Giacomelli Á, Albino CM, de Souza HDN, CorrêaVelloso J, de Jesus Santos AP, Baranova J, et al. P2Y6 and P2X7 receptor antagonism exerts neuroprotective/ neuroregenerative effects in an animal model of Parkinson's disease. Front Cell Neurosci. 2019;13:476.

140. Zhou L, Miranda-Saksena M, Saksena NK. Viruses and neurodegeneration. Virol J. 2013;10:1-17.

141. Lee S, Nedumaran B, Hypolite J, Caldwell B, Rudolph MC, Malykhina AP. Differential neurodegenerative phenotypes are associated with heterogeneous voiding dysfunction in a coronavirus-induced model of multiple sclerosis. Sci Rep. 2019;9:1-11.

142. Rey NL, Wesson DW, Brundin P. The olfactory bulb as the entry site for prion-like propagation in neurodegenerative diseases. Neurobiol Dis. 2018;109:226-48.

143. Wilkaniec A, Gąssowska M, Czapski GA, Cieślik M, Sulkowski G, Adamczyk A. P2X7 receptor-pannexin 1 interaction mediates extracellular alpha-synuclein-induced ATP release in neuroblastoma SH-SY5Y cells. Purinergic Signal. 2017;13:347-61.

144. Jiang T, Hoekstra J, Heng X, Kang W, Ding J, Liu J, et al. P2X7 receptor is critical in $\alpha$-synuclein-mediated microglial NADPH oxidase activation. Neurobiol Aging. 2015;36:2304-18.

145. Deussing JM, Arzt E. P2X7 receptor: a potential therapeutic target for depression? Trends Mol Med. 2018;24:736-47.

146. Ribeiro DE, Casarotto PC, Staquini L, Pinto E, Silva MA, Biojone $\mathrm{C}$, et al. Reduced $\mathrm{P} 2 \mathrm{X}$ receptor levels are associated with antidepressant effect in the learned helplessness model. PeerJ. 2019;7:e7834.

147. Iwata M, Ota KT, Li X-Y, Sakaue F, Li N, Dutheil S, et al. Psychological stress activates the inflammasome via release of adenosine triphosphate and stimulation of the purinergic type 2X7 receptor. Biol Psychiatry. 2016;80:12-22.

148. Ribeiro DE, Müller HK, Elfving B, Eskelund A, Joca SRL, Wegener G. Antidepressant-like effect induced by $\mathrm{P} 2 \mathrm{X} 7$ receptor blockade in FSL rats is associated with BDNF signalling activation. J Psychopharmacol. 2019;33:1436-46.

149. Bo HX, Li W, Yang Y, Wang Y, Zhang Q, Cheung T, et al. Posttraumatic stress symptoms and attitude toward crisis mental health services among clinically stable patients with COVID-19 in China. Psychological Medicine. 2020;1-9.

150. Kong X, Zheng K, Tang M, Kong F, Zhou J, Diao L, et al. Prevalence and Factors Associated with Depression and Anxiety of Hospitalized Patients with COVID-19. 2020. https://doi.org/ 10.1101/2020.03.24.20043075.

151. Kim HC, Yoo SY, Lee BH, Lee SH, Shin HS. Psychiatric findings in suspected and confirmed middle east respiratory syndrome patients quarantined in hospital: a retrospective chart analysis. Psychiatry Investig. 2018;15:355-60.

152. Cheng SKW, Tsang JSK, Ku KH, Wong CW, Ng YK. Psychiatric complications in patients with severe acute respiratory syndrome (SARS) during the acute treatment phase: a series of 10 cases. Br J Psychiatry. 2004;184:359-60. 
153. Chua SE, Cheung V, McAlonan GM, Cheung C, Wong JWS, Cheung EPT, et al. Stress and psychological impact on SARS patients during the outbreak. Can J Psychiatry. 2004;49:385-90.

154. Lee AM, Wong JGWS, McAlonan GM, Cheung V, Cheung C, Sham PC, et al. Stress and psychological distress among SARS survivors 1 year after the outbreak. Can J Psychiatry. 2007;52: 233-40.

155. Sheng B, Cheng SKW, Kwok KL, Ho LL, Chan ELY. The effects of disease severity, use of corticosteroids and social factors on neuropsychiatric complaints in severe acute respiratory syndrome (SARS) patients at acute and convalescent phases. Eur Psychiatry. 2005;20:236-42.

156. Cheng SKW, Wong CW, Tsang J, Wong KC. Psychological distress and negative appraisals in survivors of severe acute respiratory syndrome (SARS). Psychol Med. 2004;34:1187-95.

157. Mak IWC, Chu CM, Pan PC, Yiu MGC, Chan VL. Long-term psychiatric morbidities among SARS survivors. Gen Hosp Psychiatry. 2009;31:318-26.

158. Hong X, Currier GW, Zhao X, Jiang Y, Zhou W, Wei J. Posttraumatic stress disorder in convalescent severe acute respiratory syndrome patients: a 4-year follow-up study. Gen Hosp Psychiatry. 2009;31:546-54.

159. Lam MHB, Wing YK, Yu MWM, Leung CM, Ma RCW, Kong APS, et al. Mental morbidities and chronic fatigue in severe acute respiratory syndrome survivors long-term follow-up. Arch Intern Med. 2009;169:2142-7.

160. Okusaga O, Yolken RH, Langenberg P, Lapidus M, Arling TA, Dickerson FB, et al. Association of seropositivity for influenza and coronaviruses with history of mood disorders and suicide attempts. J Affect Disord. 2011;130:220-5.

161. Hiroi N, Wong ML, Licinio J, Park C, Young M, Gold PW, et al. Expression of corticotropin releasing hormone receptors type I and type II mRNA in suicide victims and controls. Mol Psychiatry. 2001;6:540-6.

162. Vindegaard N, Eriksen Benros M. COVID-19 pandemic and mental health consequences: systematic review of the current evidence. Brain Behav Immun. 2020;89:531-42.

163. Farooq RK, Tanti A, Ainouche S, Roger S, Belzung C, Camus V. A P2X7 receptor antagonist reverses behavioural alterations, microglial activation and neuroendocrine dysregulation in an unpredictable chronic mild stress (UCMS) model of depression in mice. Psychoneuroendocrinology. 2018;97:120-30.

164. Csölle C, Andó RD, Kittel A, Gölöncsér F, Baranyi M, Soproni $\mathrm{K}$, et al. The absence of $\mathrm{P} 2 \mathrm{X} 7$ receptors (P2rx7) on nonhaematopoietic cells leads to selective alteration in mood-related behaviour with dysregulated gene expression and stress reactivity in mice. Int J Neuropsychopharmacol. 2013;16:213-33.

165. Raony Í, de Figueiredo CS, Pandolfo P, Giestal-de-Araujo E, Oliveira-Silva Bomfim P, Savino W. Psycho-NeuroendocrineImmune Interactions in COVID-19: potential impacts on mental health. Front Immunol. 2020;11:1170.

166. Fleshner M, Frank M, Maier SF. Danger signals and inflammasomes: stress-evoked sterile inflammation in mood disorders. Neuropsychopharmacology. 2017;42:36-45.

167. Yin XX, Zheng XR, Peng W, Wu ML, Mao XY. Vascular endothelial growth factor (VEGF) as a vital target for brain inflammation during the COVID-19 outbreak. ACS Chem Neurosci. 2020;11:1704-5.

168. Kanellopoulos JM, Delarasse C. Pleiotropic roles of P2X7 in the central nervous system. Front Cell Neurosci. 2019;13:401.

169. Clark-Raymond A, Meresh E, Hoppensteadt D, Fareed J, Sinacore J, Halaris A. Vascular endothelial growth factor: a potential diagnostic biomarker for major depression. J Psychiatr Res. 2014;59:22-7.
170. Nowacka MM, Obuchowicz E. Vascular endothelial growth factor (VEGF) and its role in the central nervous system: a new element in the neurotrophic hypothesis of antidepressant drug action. Neuropeptides. 2012;46:1-10.

171. Ziegler CGK, Allon SJ, Nyquist SK, Mbano IM, Miao VN, Tzouanas CN, et al. SARS-CoV-2 receptor ACE2 is an interferon-stimulated gene in human airway epithelial cells and is detected in specific cell subsets across tissues. Cell. 2020;181: 1016-35.

172. Chen J, Chen Z, Chintagari NR, Bhaskaran M, Jin N, Narasaraju $\mathrm{T}$, et al. Alveolar type I cells protect rat lung epithelium from oxidative injury. J Physiol. 2006;572:625-38.

173. Regenhardt RW, Bennion DM, Sumners C. Cerebroprotective action of angiotensin peptides in stroke. Clin Sci. 2014;126: 195-205.

174. Rotermund N, Schulz K, Hirnet D, Lohr C. Purinergic signaling in the vertebrate olfactory system. Front Cell Neurosci. 2019; 13:112.

175. Sameshima T, Nabeshima K, Toole BP, Yokogami K, Okada Y, Goya T, et al. Expression of emmprin (CD147), a cell surface inducer of matrix metalloproteinases, in normal human brain and gliomas. Int J Cancer. 2000;88:21-7.

176. Radzikowska U, Ding M, Tan G, Zhakparov D, Peng Y, Wawrzyniak P, et al. Distribution of ACE2, CD147, CD26 and other SARS-CoV-2 associated molecules in tissues and immune cells in health and in asthma, COPD, obesity, hypertension, and COVID-19 risk factors. Allergy. 2020;75:2829-45.

177. Kanyenda LJ, Verdile G, Martins R, Meloni BP, Chieng J, Mastaglia $F$, et al. Is cholesterol and amyloid- $\beta$ stress induced CD147 expression a protective response? Evidence that extracellular cyclophilin a mediated neuroprotection is reliant on CD147. J Alzheimer's Dis. 2014;39:545-56.

178. Krishnamoorthy Y, Nagarajan R, Saya GK, Menon V. Prevalence of psychological morbidities among general population, healthcare workers and COVID-19 patients amidst the COVID19 pandemic: a systematic review and meta-analysis. Psychiatry Res. 2020;293:113382.

179. Xiong J, Lipsitz O, Nasri F, Lui LMW, Gill H, Phan L, et al. Impact of COVID-19 pandemic on mental health in the general population: a systematic review. J Affect Disord. 2020;277: $55-64$.

180. da Silva FCT, Neto MLR. Psychological effects caused by the COVID-19 pandemic in health professionals: a systematic review with meta-analysis. Prog Neuropsychopharmacol Biol Psychiatry. 2021;104:110062.

181. Salari N, Hosseinian-Far A, Jalali R, Vaisi-Raygani A, Rasoulpoor S, Mohammadi M, et al. Prevalence of stress, anxiety, depression among the general population during the COVID-19 pandemic: a systematic review and meta-analysis. Glob Health. 2020;16:57.

182. de Pablo GS, Vaquerizo-Serrano J, Catalan A, Arango C, Moreno $\mathrm{C}$, Ferre $\mathrm{F}$, et al. Impact of coronavirus syndromes on physical and mental health of health care workers: systematic review and meta-analysis. J Affect Disord. 2020;275: 48-57.

183. Luo M, Guo L, Yu M, Wang H. The psychological and mental impact of coronavirus disease 2019 (COVID-19) on medical staff and general public - a systematic review and meta-analysis. Psychiatry Res. 2020;291:113190.

184. Pappa S, Ntella V, Giannakas T, Giannakoulis VG, Papoutsi E, Katsaounouc P, et al. Prevalence of depression, anxiety, and insomnia among healthcare workers during the COVID-19 pandemic: a systematic review and meta-analysis. Brain Behav Immun. 2020;88:901-7. 